\title{
On the Entity and Antiquity of the Aurignacian at Willendorf (Austria): Implications for Modern Human Emergence in Europe
}

\author{
Nicolas Teyssandier ${ }^{1}$ • João Zilhão ${ }^{2,3,4}$
}

(C) Springer International Publishing AG, part of Springer Nature 2018

\begin{abstract}
The time of the Aurignacian's first appearance in the archeological record lies at the heart of debates on the emergence of European anatomically modern humans. Based on a re-study of Archeological Horizon (AH) 3 of Willendorf II, it has been claimed that the Early Aurignacian was present in the loess plains of Lower Austria by $43.5 \mathrm{ka}$ (thousands of calendar years ago), several millennia earlier than in western Europe. The claim rests on the argument that a refit set linking an area excavated 20062011 with another excavated 1908-1909 implies that the two stone tool collections derive from a single, homogeneous assemblage. Therefore, the dating of the 20062011 context would also date the Early Aurignacian diagnostics found in the 19081909 collection. Based on the published evidence, this argument cannot be supported. The 1908-1909 excavation extended way beyond the boundaries of the stratigraphic level in which AH3 was identified in 2006-2011: lens C8-3 of subunit C8. Northward, subunit $\mathrm{C} 8$ becomes internally undifferentiated and merges with subunit $\mathrm{C} 7$ above, within which a new horizon, AH3ab, was first formally recognized in 2006-2011. This evidence implies that "AH3" of 1908-1909 was a stratigraphically heterogeneous unit
\end{abstract}

Nicolas Teyssandier

teyssandier@univ-tlse2.fr

João Zilhão

joao.zilhao@ub.edu

1 CNRS UMR 5608 TRACES, Université de Toulouse Jean Jaurès, 5 allées Antonio Machado, 31058 Toulouse Cedex 9, France

2 Institució Catalana de Recerca i Estudis Avançats (ICREA), Passeig Lluís Companys 23, 08010 Barcelona, Catalonia, Spain

3 SERP (Seminari d'Estudis i Recerques Prehistòriques; SGR2014-00108), Departament d'Història i Arqueologia, Facultat de Geografia i Història, Universitat de Barcelona, c/ Montalegre 6, 08001 Barcelona, Catalonia, Spain

4 UNIARQ-Centro de Arqueologia da Universidade de Lisboa, Faculdade de Letras de Lisboa, Universidade de Lisboa, Alameda da Universidade, 1600-214 Lisbon, Portugal 
over at least half of the area then excavated and that the stone tools it yielded must be treated as a multi-component assemblage that conflates material derived from at least two different occupation horizons. In line with the chrono-stratigraphy of Europe's Early Upper Paleolithic sequence, the few Early Aurignacian diagnostics found in the "AH3" collection of 1908-1909 must date to ca.39.1 ka, the calendar age of AH3ab. The single refit set linking the two collections shows that an earlier component, dated to ca.43.5 ka by the 2006-2011 work, is also represented in the collection from 1908 to 1909. However, in the absence of diagnostics, the technocomplex affinities of that earlier component cannot be ascertained. The association of the Early Aurignacian with modern humans in Lower Austria remains a legitimate inference but is valid for the ca.38-40 ka time range, not before.

Keywords Protoaurignacian · Early Aurignacian · Neandertals · Radiocarbon · Stratigraphy

\section{Introduction}

The precise timing of modern human emergence in Europe is still hotly debated. Part of the problem resides in the scarcity of diagnostic human fossils, which even more rarely have been found in unambiguous association with clearly defined archeological contexts. Based on the speculation that modern humans made such technocomplexes as the Bohunician (cf. Hublin 2015), dates as early as 45-50 ka have been proposed. However, neither the Bohunician nor the other so-called transitional industries from the beginning of the Upper Paleolithic in eastern and central Europe have so far been found in association with human remains, while several directly dated diagnostic fossils place Neandertals from Croatia, Germany, France, and Belgium within the corresponding 45-50 ka time slot. Claims for modern humans being present at that time elsewhere in Europe, for instance at Kent's Cavern and Cavallo, are no less dubious, due to ambiguity in morphological features or poor stratigraphic context (White and Pettitt 2012; Zilhão 2013; Zilhão et al. 2015; contra Benazzi et al. 2011; Higham et al. 2011).

The first technocomplex effectively associated with modern humans in Europe is the Aurignacian, which has long been considered an archeological proxy for their dispersal into the continent. Based on the changes observed through time in bone and stone tool typology (e.g., Delporte 1984, 1991; Demars 1992; Peyrony 1933; Sonneville-Bordes 1960, 1983), this technocomplex has been traditionally subdivided into four phases: Protoaurignacian, Early Aurignacian (a.k.a. Aurignacian I), Evolved Aurignacian (a.k.a. Aurignacian II or Recent Aurignacian), and an as-yet poorly known and poorly defined Late Aurignacian (a.k.a. Aurignacian III-IV).

In Southwest France, where we have the most robust datasets and several clear archeo-stratigraphic successions, the chronological value of this scheme is unquestionable. For instance, whenever the two earlier phases are represented at the same site - as is the case at Les Cottès, Le Piage, Brassempouy, Gatzarria, Les Abeilles, or Isturitz, among others-the Protoaurignacian always precedes the Early Aurignacian stratigraphically. This precedence is replicated by a quality control-filtered corpus of radiocarbon dates for the Protoaurignacian, the Early Aurignacian, and the Evolved Aurignacian. Under a stratigraphic precedence prior, this corpus yields a robust 
chronological model with few outliers and well-defined boundaries: the 40.0-39.2 ka interval for the transition from Protoaurignacian to Early Aurignacian and the 37.0$36.5 \mathrm{ka}$ interval for the transition from Early Aurignacian to Evolved Aurignacian (Banks et al. 2013a, b).

The modern human fossils from the Peștera cu Oase, in Romania, are directly dated to the 38-42 ka interval (Trinkaus et al. 2013). Given the width of the uncertainty interval and the absence of an immediate archeological context, assigning them to either the Early Aurignacian or the Protoaurignacian, both documented in the wider vicinity, is equally plausible. At the least, these fossils establish an association between modern humans and the Early Aurignacian. In Southwest France, such an association is further supported by the two fragmentary but diagnostic mandibles from level 3 of La Quina-Aval, dated to around $38 \mathrm{ka}$ (Verna et al. 2012; Dujardin 2001), and by the coeval dental series from Brassempouy, which is also considered to represent modern humans (Bailey and Hublin 2005; but see Henry-Gambier et al. 2004). In addition, no diagnostic Neandertal remains exist in the intervening geographical space that can be securely archeologically associated with the Early Aurignacian, or reliably directly dated to the corresponding time span. Claims to the contrary, based on the Croatian site of Vindija (for a summary, cf. Karavanić and Smith 2014), have been refuted with archeological arguments (Zilhão 2009), now corroborated by radiocarbon dating (Devièse et al. 2017).

Combined, the evidence from Oase and the Aquitaine sites makes it legitimate to infer that, by Early Aurignacian times, the mid-latitude lands of Europe along the Danube corridor were inhabited by anatomically modern humans all the way from Romania in the east to France in the west (Fig. 1). Therefore, use of the perceived Early Aurignacian affinities in the lithic assemblage from Archeological Horizon (AH) 3 of Willendorf II, in Lower Austria, as a proxy for the local presence of modern humans in the corresponding time range, is appropriate (Nigst et al. 2014). However, these authors also claim a date of $\geq$ $43.5 \mathrm{ka}$ for this context, several millennia earlier than everywhere else.

If true, the precocious presence of Aurignacian modern humans in Lower Austria would have major implications for debates on the origins of behavioral modernity and the interpretation of the cultural innovations seen after $50 \mathrm{ka}$ in the archeological record of Europe. For instance, it would make it possible to contemplate scenarios whereby such cultural innovations-e.g., the use of jewelry in the Châtelperronian culture of southwestern France and northern Spain-would signify the acculturation of Châtelperronian Neandertals by nearby modern humans (Hublin 2015), if not that, like the Bohunician and the other "transitional" industries, the Châtelperronian itself might have been made by modern humans too (Bar-Yosef and Bordes 2010). In light of Banks et al.'s (2013a, b) modeling results, however, the claim for a greater antiquity of the Aurignacian at Willendorf represents a chrono-stratigraphic anomaly. It therefore raises the three related questions that we address here:

- Is the AH3 stone tool assemblage homogeneous?

- Is there a truly Early Aurignacian component in the AH3 stone tool assemblage?

- How secure is the association between the AH3 lithics and the charcoal samples used to date it? 


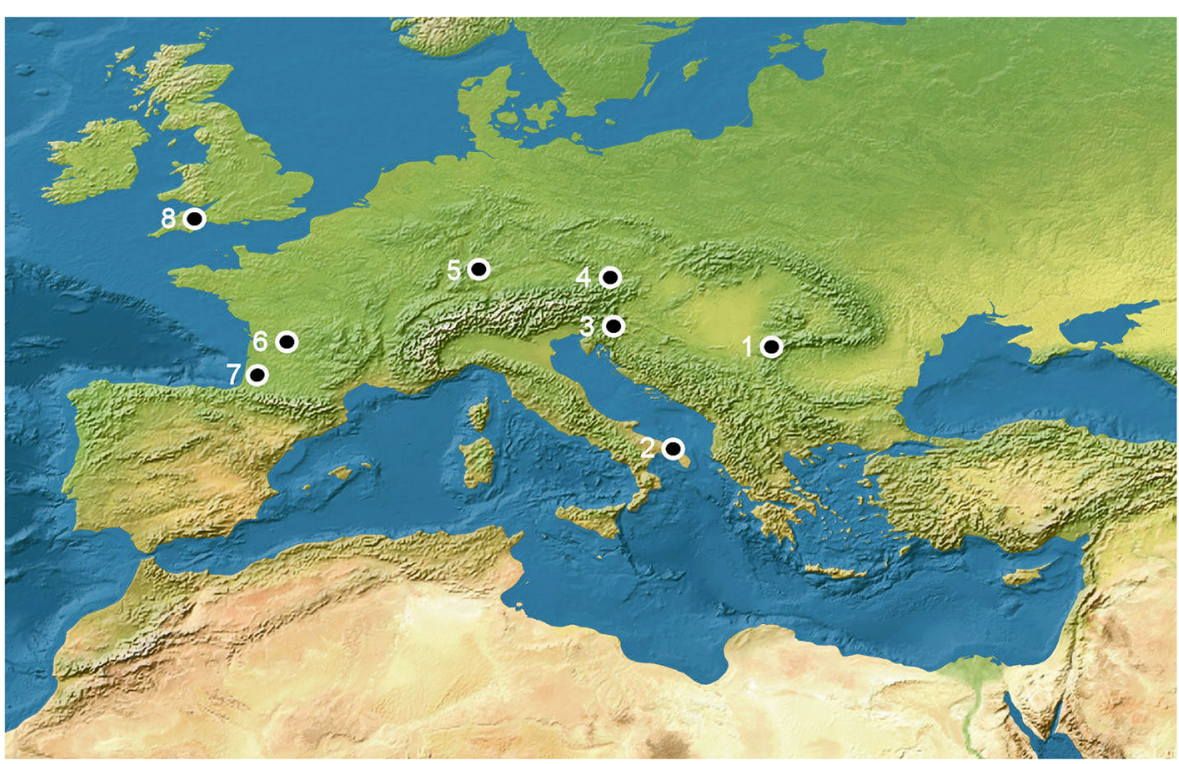

Fig. 1 Location of the sites mentioned in the text (plotted on NE2_50M_SR_W.tif, available at http://www. naturalearthdata.com/downloads/50m-raster-data/50m-natural-earth-2/). 1: Oase; 2: Cavallo; 3: Vindija; 4: Willendorf; 5: Geissenklösterle; 6: La Quina; 7: Brassempouy; 8: Kent’s Cavern

In the following, we examine these questions based on hands-on familiarity with the stone tool assemblages from the earlier excavations (Teyssandier 2007), the study of the associated documentation, and the published evidence concerning the new, 2006-2011 phase of work at the site. Because our inquiry is largely based on a historical, critiqueof-the-sources approach, we illustrate our points with reproductions of the printed material upon which lie the foundations of our argument, with only the minimal modifications required to enhance readability. We provide a synthesis at the end, but caution that full understanding of our case requires that the reader be willing to delve into the minutiae of site stratigraphy and excavation history.

\section{Issues of Theory and Definition}

\section{What Is the Early Aurignacian?}

Among the cultural entities currently recognized at the beginning of the Upper Paleolithic in Europe, the Aurignacian finds its technological identity in the use of a projectile system whereby the point mounted on the shaft is made of organic material (antler or wood) and is armed laterally, for additional penetration or cutting power, with microlithic inserts: the family of so-called Dufour bladelets, which comprises several subtypes (Le BrunRicalens 2005; O'Farrell 2005; Falcucci et al. 2016). This system sets it apart from both preceding and succeeding entities, in which projectiles were axially stone-tipped. Among these entities, the Mousterian, Châtelperronian, Bohunician, Szeletian, and Jerzmanowician points each define a separate pre-Aurignacian technocomplex named after the site where the specific lithic point type was first identified. The same is true for the 
Gravette point, which defines the subsequent Gravettian. The functional interpretation of these typological points as actual projectile tips is supported by use-wear analysis and the presence of diagnostic impact fractures (e.g., for the Mousterian points, Villa et al. 2009, Lazuén 2012 and Zilhão et al. 2017, or, for the Jerzmanovician points, Jacobi 1990), even though wear indicative of other uses (e.g., as knives) has also been reported.

Within the Aurignacian, the variation underpinning its subdivision into temporal phases concerns the different methods used to produce bladelet blanks for the organic points' lithic inserts. For instance, the Evolved Aurignacian features a more diverse range of specialized bladelet cores (e.g., the nosed "scraper" or the busked "burin"), and, as a result, the range of retouched bladelets is typologically more diverse than during the Protoaurignacian or the Early Aurignacian. In addition, the Early Aurignacian differs from the Evolved Aurignacian in the morphology of the organic points themselves - split-based in the former, massive-based in the latter - while the Protoaurignacian contrasts with both in the overall organization of stone tool production (Bon 2002; Bordes 2006; Teyssandier

Table 1 Protoaurignacian vs Early Aurignacian lithic technology

\begin{tabular}{|c|c|c|}
\hline Feature & Protoaurignacian & Early Aurignacian \\
\hline $\begin{array}{l}\text { Core } \\
\text { reduction }\end{array}$ & $\begin{array}{l}\text { Continuous blade/bladelet production from } \\
\text { unidirectional cores set-up on either blocks } \\
\text { or flakes, often with a pyramidal morphol- } \\
\text { ogy; bladelets can also be obtained sepa- } \\
\text { rately from volumes whose smaller size } \\
\text { does not allow for an initial phase of blade } \\
\text { production }\end{array}$ & $\begin{array}{l}\text { Two distinct reduction sequences, one for } \\
\text { blades (with which the Evolved } \\
\text { Aurignacian blade technology lies in broad } \\
\text { continuity), another for bladelets }\end{array}$ \\
\hline $\begin{array}{l}\text { Core } \\
\text { prepara- } \\
\text { tion }\end{array}$ & $\begin{array}{l}\text { Generally, unfaceted striking platforms, with } \\
\text { blanks being extracted by direct, marginal } \\
\text { percussion with soft-stone or soft-organic } \\
\text { hammers }\end{array}$ & $\begin{array}{l}\text { Minimal pre-forming of blade cores; opening } \\
\text { crests are rare and show minimal invest- } \\
\text { ment; a single striking platform is used and } \\
\text { rejuvenated through the removal of thick } \\
\text { core tablets; the single striking platform is } \\
\text { carefully prepared, resulting in facetted or } \\
\text { spurred butts on most products }\end{array}$ \\
\hline $\begin{array}{l}\text { Blank } \\
\text { production }\end{array}$ & $\begin{array}{l}\text { The emphasis is put on the fabrication of long, } \\
\text { rectilinear blanks detached from the center } \\
\text { of the flaking surface }\end{array}$ & $\begin{array}{l}\text {-Robust blades removed by direct percussion } \\
\text { with soft, organic hammers; the "ideal" } \\
\text { blade (i.e., that which will be used as a tool } \\
\text { blank) is large and, above all, wide and } \\
\text { thick; its profile is in general curved, and } \\
\text { some cortex often remains } \\
\text {-Short bladelets with a relatively curved } \\
\text { profile, extracted from carinated cores, } \\
\text { once considered to be "scrapers" and the } \\
\text { chief contributors to the traditional } \\
\text { typological identity of the Aurignacian in } \\
\text { general }\end{array}$ \\
\hline $\begin{array}{l}\text { Modification } \\
\text { of blade } \\
\text { blanks }\end{array}$ & $\begin{array}{l}\text { Transformed into burins and endscrapers, } \\
\text { lateral retouch being rare and the so-called } \\
\text { Aurignacian retouch virtually absent }\end{array}$ & $\begin{array}{l}\text { Mostly retouched into endscrapers and } \\
\text { "Aurignacian blades" (laterally retouched } \\
\text { blades that can often be repeatedly and } \\
\text { heavily resharpened) }\end{array}$ \\
\hline $\begin{array}{l}\text { Modification } \\
\text { of bladelet } \\
\text { blanks }\end{array}$ & $\begin{array}{l}\text { Pointed by bilateral, direct retouch and/or } \\
\text { edge-trimmed through inverse or alternate } \\
\text { retouch (Dufour bladelets sensustricto) }\end{array}$ & $\begin{array}{l}\text { Seldom retouched; when they are, the retouch } \\
\text { is semi-abrupt or marginal, mostly inverse, } \\
\text { and tends to concern the right edge }\end{array}$ \\
\hline
\end{tabular}


Table 2 The split-based point as an index fossil of the Early Aurignacian. Critique of putative occurrences in the Protoaurignacian or the Evolved Aurignacian

Occurrence Critique

Trou de la Mère Clochette Szmidt et al. (2010) describe as wing fragments of split-based bone points two directly dated bone objects found in association with a stone tool assemblage assigned to the Protoaurignacian. While material suggestive of the Protoaurignacian exists among the lithics, the typological classification of the dated samples and the homogeneity of the stratigraphic context is questionable (Banks et al. 2013a, b). The lithics were collected in the "yellow layer" (Unit B), whose thickness varied between $10 \mathrm{~cm}$ and $1 \mathrm{~m}$ and whose content included such clearly intrusive material as a human maxilla directly dated to $4341 \pm 33$ BP (OxA-X-2278-26). In addition, the direct dates for the putative split-based point fragments are statistically distinct. One $(33,750 \pm 350 \mathrm{BP}$; OxA-19621) falls in the time range of the Early Aurignacian. The other $(35,460 \pm 250 ;$ OxA-19622) does fall in the time range of the Protoaurignacian. Per Szmidt et al. (2010: 3328), the latter would bear "scraping marks which are less visible on its exterior surface due to the presence of cancellous material, but much more obvious ones on its lateral edge facets." However, no such marks are apparent in the published illustrations.

Grotte du Renne at Arcy-sur-Cure

Riparo di Fumane

Divje babe I
Julien et al. (2002) describe a split-based bone point fragment from Protoaurignacian layer VII. Because of the small size of the fragment, its classification as the wing of a split-based point must remain speculative at best.

Levels A1 and D3, in the upper part of the Aurignacian sequence, yielded two split-based points. Higham et al.'s (2009) Bayesian model of the sequence places the boundary between A1 and the underlying, strictly speaking Protoaurignacian level A2 in the 40.5-38.9 ka interval. Put another way, A1 and D3 above must fall in the time range of the Aurignacian I, as otherwise corroborated by the ca.38.3 ka date $(33,890 \pm 220$ BP; OxA-17981) obtained for layer D3 itself. In the Italian research tradition, influenced by Laplacian systematics, the term Protoaurignacian is often used in a generalized cultural or geographical sense - the Protoaurignacian as the specific Italian form of the Aurignacian as a whole (Palma di Cesnola 1993). The fact that two rather different concepts are expressed with the same word in two different research traditions creates confusion, but the Fumane pieces date to the time range of the Aurignacian I.

Based on an osseous point directly dated to $29,760 \pm 340$ BP (OxA-28219), Moreau et al. (2015) claim that "a strict sequential order of appearance of these type-fossils (split-based and massive-based) in Central Europe, in comparison with the culture-stratigraphic framework of SW France, is unlikely." However, in no way can the dated specimen (Moreau et al. 2015, Fig. 6) be considered a split-based point. The base of the object features an en languette break rarely if at all found among such points. In addition, when seen in profile view, the split in split-based points is always centrally placed, along the axis. Yet, the dated Divje babe I object shows smooth, bifacially shaped edges from tip to base. In fact, this is a massive-based bone point that, on one of the sides, is missing a flaked-off flat fragment.

2007, 2008) (Table 1). Note that close examination of the claims that the split-based point can also be found in the Protoaurignacian and in later phases of the technocomplex cannot be supported; this bone tool-type is a true index fossil of the Early Aurignacian (Table 2).

The different components of the Early Aurignacian lithic reduction system thus seem to be tethered to the activities the intended end-products were to be used in, i.e., the system 
responds in fairly direct manner to a sort of domestic vs. hunting tool dichotomy (Tartar et al. 2006; Teyssandier et al. 2010). This separation of functional spheres is also seen among the bone tools (Liolios 1999, 2006): antler was mainly selected for the making of split-based points and percussion implements; bone was used for making awls, polishers, and retouchers; and ivory was preferred for mobiliary art and ornaments (Teyssandier and Liolios 2003, p. 188). No such raw-material economy seems to be in operation during the Protoaurignacian.

In Southwest France, exclusive types of personal ornaments, such as the perforated human teeth from Le Combe, Brassempouy, Isturitz and Tarté, or the ivory basket-shaped bead, are another important aspect of the Early Aurignacian material culture repertoire (White 2007a, b). The basket-shaped bead is a particularly interesting case because it occurs in large quantities, is characterized by a specific operational chain, and features a welldefined geographical distribution. As underlined by White, this "highly redundant set of procedures seems not to extend southward across the Spanish frontier and is unknown north of the Aquitaine basin" (White 2007b: 296). Strong indicators of cultural unity across the Aquitaine basin exist in other aspects of the symbolic realm - for instance, the vulvar imagery shared by several Early Aurignacian sites in the Vézère valley (White et al. 2012).

Such a commonality of culture is also apparent at the territorial analysis level. For instance, Early Aurignacian lithic raw-material procurement patterns show Southwest France being crisscrossed by N-S connections that are apparent even when the size of the assemblages is small. Flint from Pyrenean sources (e.g., Chalosse flint) is systematically found in northern Aquitaine. Conversely, Dordogne or Charente sources are well represented in tool-kits from Basque and Pyrenean sites (Bordes et al. 2005; Féblot-Augustins 2008; Anderson et al. 2015). Such connections are replicated in the domain of bead manufacture: the Dordogne has sites with massive production (such as Castanet), while the signature seen in the Basque and Pyrenean sites is one of maintenance (e.g., Brassempouy) or "no-production-whatsoever" (e.g., Isturitz). This pattern supports a "model of ornament fabrication within a regional system of seasonal movement and site function" (White 2007b, p. 300).

At the scale of Southwest France, the Early Aurignacian is therefore a very homogeneous entity, one in which intra-regional variation exists in the context of extensive inter-regional connections. Clearly, a long-term, well-established social network must underpin this pattern. Much the same can be derived from the rather tight clustering of radiocarbon dating results. Even though the total uncertainty interval associated with individual ages reaches $36 \mathrm{ka}$, the dated samples' stratigraphic constraints imply for this regional manifestation of the Early Aurignacian the same chronology as elsewhere in Europe- the ca.40-37 ka interval.

\section{What Is a Technocomplex?}

Within Clarke's systematization of archeological entities, technocomplexes are "groups of cultures characterized by assemblages sharing a polythetic range but differing specific types of the same general families of artefact types, shared as a widely diffused and interlinked response to common factors in environment, economy and technology" (Clarke 1978, p. 206). Especially when direct dates on the fossils themselves are unavailable and their age assignment is based on the archeology they are associated with, keeping this definition in mind when discussing modern human emergence in Europe is key to avoid the reification 
trap (Teyssandier and Liolios 2008). Put another way, issues of definition must be kept at the heart of our inquiry if we want to learn about the empirical reality that our concepts are designed to let us understand - as opposed to artificially imposing ontological "reality" onto thought constructs whose entity derives solely from language and then derive inferences of empirical equivalence, identity, or distinction that result solely from the words used (Zilhão 2006).

By affirming appurtenance to the "Aurignacian technocomplex" of the archeological occurrences at stake, claims for the Early Aurignacian (and, hence, modern humans) to be found in central Europe millennia before they are first seen in Southwest France implicitly accept Clarke's (1978) system. In the context of this system, the "Aquitanian Aurignacian" can be defined as a "culture group," if not a "culture," within the technocomplex as a whole. Likewise, any Aurignacian assemblages from central Europe can be expected, if nothing else because of geographical distance, to represent cultures or culture groups distinct from the Aquitanian one. However, they can only be considered "Aurignacian" if they share with the "Aquitanian Aurignacian" the basics of the latter's definition at the technocomplex level. If they do, we will then expect other aspects of the "Aquitanian Aurignacian" package to also be present-even if, to use Clarke's words, "differing in specific types of the same general families of artefact types." For instance, we will expect objects of personal ornamentation to be found in central Europe as well, even if made of stone or amber instead of ivory, or, if made of ivory, to be, say, disk-shaped as opposed to basket-shaped. More to the point, we will be allowed legitimately to infer that such families of artifact types must exist in the repertoire of a given central European culture or culture group of the Aurignacian technocomplex even if absent at the specific locality or localities under study.

In this theoretical context, however, claiming that a given assemblage belongs in the Aurignacian technocomplex carries an implication of contemporaneity with the "Aquitanian Aurignacian" and other cultures or culture groups within the technocomplex - and ditto for each of the successive phases into which the technocomplex is subdivided. This is because of the concept's unity and discreteness in both the spatial and the temporal dimensions. In Clarke's words, a technocomplex is "the material manifestation of cultural convergence within a common stable environmental strategy" (Clarke 1978, p. 206). Put another way, to claim that a given central European occurrence belongs to the Aurignacian technocomplex, or to one of its specific phases, but dates from three to five millennia before that technocomplex or phase is known to emerge everywhere else, is, quite simply, a contradiction in terms.

The unity and discreteness, with respect to technology, culture, and adaptation, that the technocomplex concept stands for in no way extends, however, to the realm of human biology, whether at the genotype or the phenotype level. In Clarke's sense, technology, culture, and adaptation can be shared across "racial" or "ethnic" boundaries, which, if they exist within the geographical span of a technocomplex, may be expressed (possibly, but not necessarily) at the culture or culture group level-and we do know, for instance, that the Mousterian technocomplex was made by both modern humans (e.g., at Skuhl and Qafzeh) 
and Neandertals (e.g., at Kebara) (Akazawa et al. 1998). Thus, the reason why we can legitimately infer from "the Early Aurignacian is present at Willendorf" that "modern humans were present in Lower Austria at the time the site's Early Aurignacian implements were in use at the site" does not reside in the pre-Clarke, Breuil/Kossina notion that the taxonomic constructs of archeology correlate with true cultures, or true "races," in the ethnographic, or the anthropological senses. Rather, the reason why the inference is valid resides in the empirical observation that, in central Europe, the time range of the Early Aurignacian-understood as an Aurignacian phase with defined chronological boundaries-post-dates the time of Neandertal/modern human contact and ensuing Neandertal assimilation into the wider modern human gene pool.

Within a Clarkeian framework, putting Willendorf's Early Aurignacian ca.43.5 ka therefore carries the implication that the technocomplex has so far been inaccurately dated everywhere else. Ironically, such a chronology would also imply that Neandertals, not modern humans, had been its makers. Within this theoretical framework, the alternatives are that (a) the assignment of Willendorf's AH3 to the Early Aurignacian is erroneous, (b) the ages obtained for that horizon are inaccurate, or (c) the assignment is correct and the ages are accurate but the association between the samples and the archeology they are supposed to date is unwarranted.

\section{Can an Aurignacian Point of Origin Be Found?}

From outside Clarke's theoretical framework, notions of the type "Early Aurignacian modern humans are millennia earlier at Willendorf than everywhere else" could conceivably stand, for instance under early twentieth-century views of "archeological culture=ethnic culture=human type." In modern human emergence debates, a common thread in positions affirming "much earlier than hitherto thought" occurrences of fossils or of their archeological proxies is indeed that such occurrences represent (a) the "origins" of the given culture/innovation (i.e., the space/time point from which it would subsequently spread) or (b) its makers' pioneer settlement of the place of occurrence. In the context of interpreting the Middle-to-Upper Paleolithic transition in Europe, two examples of this line of thinking immediately come to mind: the notion that, at the beginning of the Upper Paleolithic, the Swabian Jura was a special locus of innovation in art and culture (the Kulturpumpe model; Conard and Bolus 2003, 2008), and the notion that certain archeological contexts - e.g., the Early Aurignacian of Lower Austria, or the Bohunician of Moravia - stand for Danubian spearheads of modern human immigration (e.g., Müller et al. 2011).

Such notions, however, are at odds with everything we know about the demography and social organization of hunter-gatherers. Among mobile groups moving across sparsely populated landscapes, no site or cluster of close-by sites can be the "origin" of a culture. A large town or a city might, because they will harbor populations that are sufficiently large for genetic and cultural endogamy to engender innovations that remain circumscribed to its boundaries long enough for a pattern of presence/absence to appear in comparisons with neighboring territories. However, based on inference from the ethnographic present, Paleolithic societies 
would have featured very low population densities and would have consisted of networks of bands with fluctuating membership and governed by the rules of exogamy. In such a context, innovations that are sufficiently important and adaptive to become archeologically recognizable necessarily emerge at the scale of territories much larger than the site; they emerge at the scale of the territories across which the social networks operate.

Based on the above, let us now consider the implications of demographic and social constraints for the assessment of "Aurignacian-earlier-than-everywhereelse" interpretations of Willendorf. Following Tallavaara et al. (2015), the carrying capacity of Lower Austrian environments during the Upper Paleolithic would have varied between 0.1 and 4 inhabitants $/ 100 \mathrm{~km}^{2}$, while Wobst (1974) has shown that, in the Paleolithic, the minimum number of persons required to form a viable reproductive network (the "maximum band") is 175. In Lower Austria, any such network would therefore range across a territory of between 4375 and $175,000 \mathrm{~km}^{2}$. Put another way, a "minimum band" of 25 individuals occasionally using Willendorf as a camp site would exert direct and immediate cultural influence over neighboring bands living within a radius of minimally some $40 \mathrm{~km}$ and possibly as much as $240 \mathrm{~km}$ - and would be directly influenced by them too. Indirectly, such an influence would in turn extend across similar distances beyond the territories of other "minimum bands." The potential amount of geographical space implicated is easy to picture once we bear in mind that those radii multiply very quickly as we factor in the indirect connections between non-adjacent nodes of the web made possible via those situated in intermediate position.

Given these numbers, and bearing in mind that 500 to 1000 years is, at best, the minimum amount of time into which radiocarbon dating allows us to resolve the Middle-to-Upper Paleolithic transition, such webs of connection imply that a Willendorf-invented Aurignacian would have spread "instantaneously" (i.e., dated by statistically identical radiocarbon results) as far as the Aquitaine basin to the west and the Black Sea shores to the east. In such a scenario, the original locus of the invention, i.e., the place/time of living of the inventor(s), would quite simply be invisible to the modern observer. For a temporal precedence effect to be amenable to detection, a major barrier to diffusion and exchange, one across which no band network connections operated, would have to exist. But what kind of a barrier might one postulate in the case at stake here? Certainly not a geographical one, as that would contradict the very notion of the Danube as the highway-to-Europe that underpins "modern human spearhead" models. Alternatively, it might be possible to argue for a biological barrier-the modern human pioneers' inability, or unwillingness, to mate or exchange with Neandertal groups occupying adjacent territories. It is now clear, however, that extensive Neandertal/ modern human admixture at the time of contact in Europe was the rule, not the exception (Smith et al. 2005; Trinkaus 2007; Pääbo 2015).

Endorsing Nigst et al.'s (2014) chronological model for Willendorf's Aurignacian therefore entails that the Aurignacian be considered as an ethnic entity, not as a technocomplex, and that such an entity (a) emerged in a territory around the 
site whose radius could have been no smaller than $40 \mathrm{~km}$ and probably had to be of as much as $240 \mathrm{~km}$ and (b) persisted therein in isolation for some 3500 years until it began to spread elsewhere. The implication of (a) is that coeval occurrences ought to exist within that territory-but none exist. The implication of (b) is that a small group of primeval Willendorfian Aurignacians either managed to reproduce themselves in complete endogamy for some 175 generations thereafter or managed to maintain a separate cultural identity despite the many hundreds of episodes of mating exchange that, under exogamy, must have taken place subsequent to the original invention of the new technology-but that is theoretically highly unlikely.

\section{Willendorf II and Its Archeological Horizon AH3}

No matter how we approach the issue, the chronology claimed for the Early Aurignacian of Willendorf entails insolvable contradictions with the theoretical premises under which Paleolithic archeology has operated for more than a century. Before resigning ourselves to the implication that we must begin again from scratch, it is therefore prudent to examine the soundness of the claim's empirical basis. The more so since, in the case of the comparable arguments put forth for another central European site, the Geissenklösterle (Higham et al. 2012, 2014), it has already been shown that the available dating results in no way imply assigning to its Early Aurignacian occupations an age beyond "normal" (Zilhão 2013; Discamps et al. 2015).

\section{Site Layout and Stratigraphy}

Willendorf II belongs to a cluster of Upper Paleolithic sites found on the Wachau, a stretch of the Danube valley some $80 \mathrm{~km}$ west of Vienna. Known for its long loesspaleosol stratigraphic sequence including several archeological horizons, the site was first excavated by the Museum of Natural Sciences of Vienna, from 1908 to 1927 (Bayer 1930), and by the University of Vienna, in 1955 (Felgenhauer 1956-1959). Modern work began in 1981, when a small trench was cut through the extant western wall and sampled for radiocarbon dating (Haesaerts 1990). In 1993, this trench was expanded into a 5.5-m-high and 3-m-wide section (Fig. 2) by a joint team of the Royal Belgian Institute of Natural Sciences and the University of Vienna (Damblon et al. 1996; Haesaerts et al. 1996).

The last phase of work at the site was by Ph. Nigst and colleagues, between 2006 and 2011 (Nigst et al. 2008a, b, 2014; Nigst and Haesaerts 2012). They re-exposed and identified key features of the earlier twentieth-century trenches, which enabled them to draw a comprehensive layout of the locality. The datum they used was placed $105 \mathrm{~m}$ to the south of that used by previous workers, which needs to be kept in mind when comparing their plans and sections with those of Felgenhauer and Haesaerts (Fig. 3a).

Thanks to Nigst et al.'s work, previous ideas about the relative position of the different trenches could be corrected. For instance, Haesaerts's 1993 trench had been thought of as being "in lateral continuity with remnants of a fireplace within cultural layer 3 


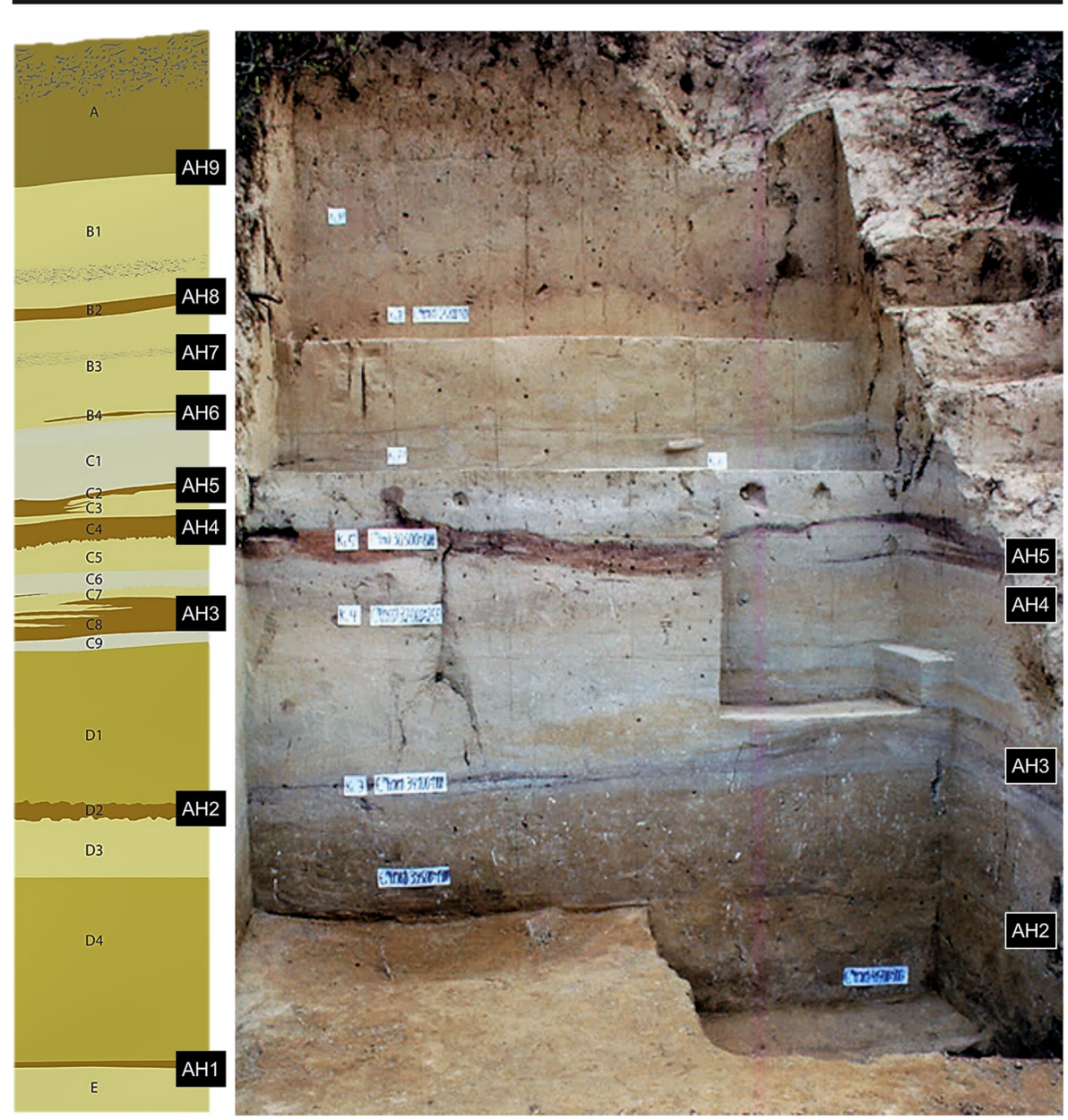

Fig. 2 Haesaerts's 1993 trench. Left: stratigraphic log. Right: photo of the labeled trench walls. After Nigst et al. (Nigst et al. 2008a, Figs. 2 and 5), modified. Note how, in this part of the site, subunits C7 (where, $12 \mathrm{~m}$ southward, $\mathrm{AH} 3 \mathrm{ab}$ has been defined) and $\mathrm{C} 8$ (where $\mathrm{AH} 3$ is comprised) merge into a single humic horizon. Differentiating within this humic horizon the individual C8-3/AH3 and C71/AH3ab lenses was only possible further downslope

encountered by J. Bayer in the NW corner of the 1908-1911 area, only partly excavated at that time" (Haesaerts and Teyssandier 2003, p. 136; Fig. 3b). However, Nigst et al. (2008a, b, 2014) have shown that no such continuity exists: in fact, the southern edge of the 1993 trench lies 3 m northward of the NW corner of the 1908-1909 trench.

Six loessic and humic bodies have been recognized at Willendorf II (Fig. 2). The lowermost ones (Units G-E) are not represented in the main excavation trenches, where the succession is capped by a Holocene soil, Unit A. Unit B below belongs to the late Pleniglacial and contains four archeological horizons-from AH9, at the top, to AH6, at the base - that yielded stone tools of Gravettian affinities. Unit $\mathrm{C}$ is about $2.7 \mathrm{~m}$-thick and is comprised of a complex set of loess layers and pedological horizons subdivided into nine subunits: from $\mathrm{C} 1$ at the top to $\mathrm{C} 9$ at the bottom. Three archeological horizons 


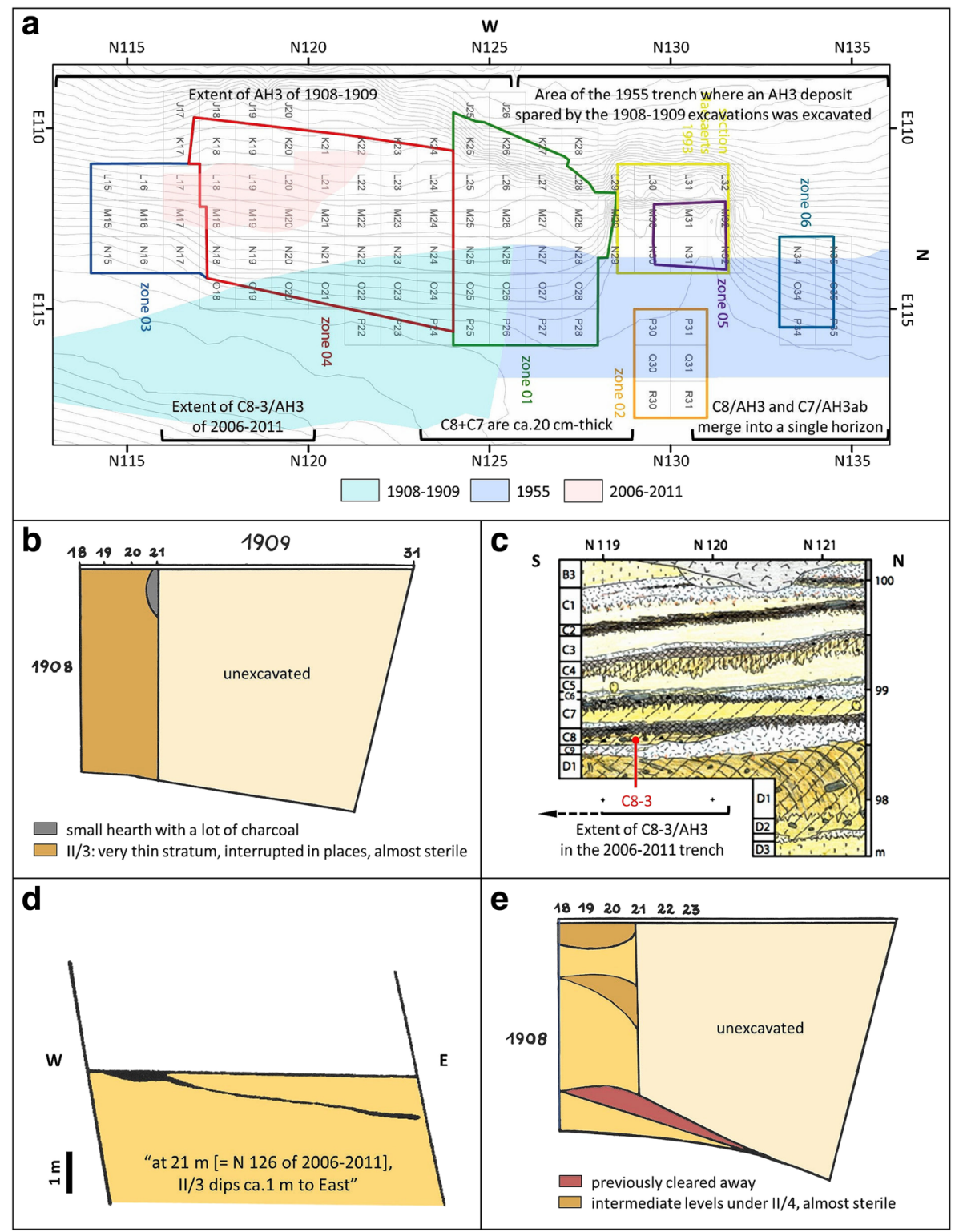

Fig. 3 Willendorf II site layout and relevant planimetric and stratigraphic data. a The 2006-2011 excavation zones, the areal extent of the C8-3 lens as recognized in 2006-2011, and the areal extent of AH3 as excavated in 1908-1909 and in 1955. b The northernmost $3 \mathrm{~m}$ band of the 1908-1909 excavation trench, showing how the archeological horizon then described as AH3 extended to its edge. c Stratigraphic log in the southern half of Zone 04 of the 2006-2011 excavation, showing how the C8-3 lens, where the artifacts then assigned to AH3 were retrieved, did not extend northward beyond N 120. d Schematic north profile of the 1908-1909 trench showing the marked eastward dip of the unit then defined as AH3. e The northernmost $3 \mathrm{~m}$ band of the 1908-1909 excavation trench, showing how intermediate levels between AH3 and AH4 were found at N 126 of the new grid and continued into the area excavated in 1955, > 5 m northward of where AH3ab was formally recognized in 2006-2011. a, c: after Nigst et al. 2014, modified; b, d-e: after Felgenhauer 1956-1959, modified 

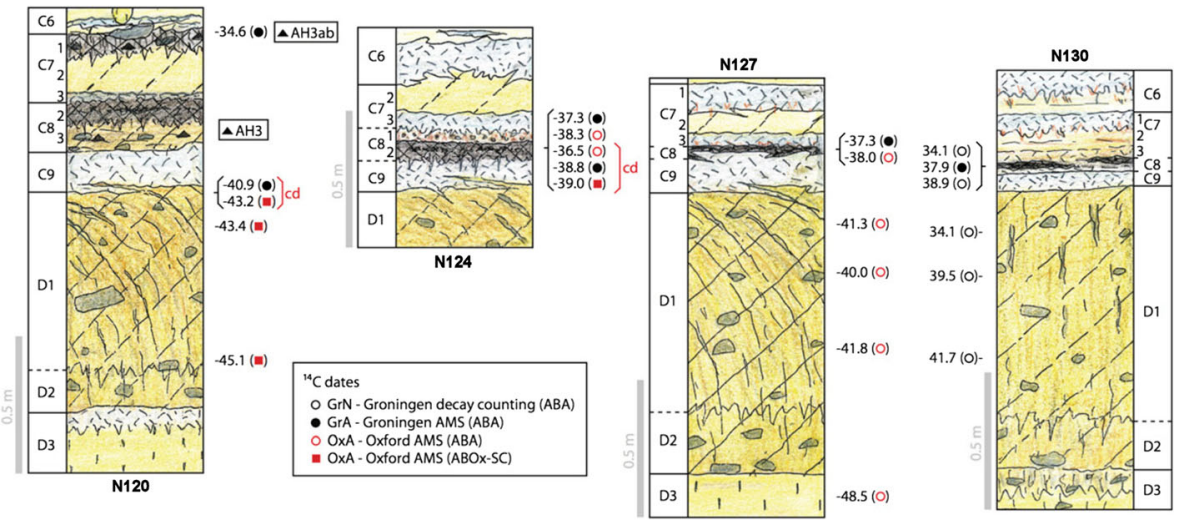

Fig. 4 Stratigraphic sections and position of key dated samples. The ages are expressed in uncalibrated thousands of years BP. The "cd" label applies to results from a cross-dating experiment. After Nigst et al. (2014), modified

(from $\mathrm{AH} 5$, at the top, to $\mathrm{AH} 3$, at the bottom) have been defined within Unit C: AH5 has been assigned to the Gravettian, AH4 to the Evolved Aurignacian, and AH3 to the Early Aurignacian. Unit D is a colluvial deposit separated by faint erosion and marked by the development of thin frost wedges. The archeological horizons found therein are of uncertain affinities. One charcoal sample collected in subunit D1 and dated with the ABOx-SC (Acid-Base-wet Oxidation and Stepped Combustion) process places the deposition of its "top" part in the 47.4-45.6 ka interval, thereby setting a maximum age for the archeology contained in the overlying AH3 horizon (Fig. 4).

The identification of stratigraphic subunit $\mathrm{C} 8$ with archeological horizon $\mathrm{AH} 3$ underpins the use of charcoal samples from the 1981-1993 trench to date the artifacts from the 1908-1909 excavations. Among such C8 dates, an initial conventional result from Groningen placing AH3 in the 35.9-40.9 ka interval has since been considered to represent a minimum age resulting from incomplete decontamination of the dated charcoal. Thus, it is the 41.7-44.3 ka interval derived from two other Groningen samples (Fig. 4) that subsequently has been retained as the best estimate for the age of AH3. These Groningen samples were all taken from the same "ashy stripes of subunit C8" (Haesaerts and Teyssandier 2003), further described by Nigst (2006, p. 272) and Nigst et al. (2008a, 2008b) as "brownish grey lenses stretched by solifluction" or as "ashy stripes with high concentrations of charcoal."

Benefiting from observations made in 2006-2011 and additional dating, Nigst et al.'s (Nigst et al. 2014, Supplementary Information, section 3.2) rendering of the archeo-stratigraphic position of AH3 is somewhat different and significantly more precise than previously reported. They recognize three different lenses (from top to bottom, C8-1, C8-2 and C8-3) within subunit C8, as follows:

"In the southern part of the site, the top of C9 is eroded by a shallow gully with scattered gravel at the base, filled by the sandy loam of C8-3 (...). The 
sedimentation also coincides with human occupation of the site, as documented by lithic artifacts and bone fragments of AH3. Afterwards, bioturbated pararendzina C8-2 developed on top of the sandy loam (...). Numerous Picea/Larix and Picea charcoal concentrations in the upper part of the humic horizon, linked to natural fires, provided radiocarbon dates 39.0 and $38.9 \mathrm{ka} \mathrm{BP}$ for this pedogenesis (...). Locally, faint erosion of the humic horizon C8-2 leads to redeposition of humic pellets in layer C8-1".

By this revision, $\mathrm{AH} 3$ is included in the $\mathrm{C} 8-3$ lens. As no radiocarbon dating results were obtained for that lens, the age of the archeological horizon is derived from the terminii provided by the dated geological levels that stratigraphically sandwich it: subunit D1 (below), and the C8-2 lens (above). Note, however, that the sandwiching is based on inference, not observation. The C8-2 samples come from grid units located between $\mathrm{N}$ 124 and N 130 of the 2006-2011 grid. Specifically, the single ABOx-SC result for C8-2 $(39,000 \pm 500 \mathrm{BP} ; \mathrm{OxA}-23520 ; 43,226-42,504$ cal BP at $2 \sigma)$ was collected in the humic horizon at N 124 (Fig. 4), while the 2006-2011 excavation found C8-3 to be present only in grid units between N 116 and N 120 (Figs. 3a, c and 4).

\section{AH3: The Definition}

Is the notion that the charcoal found in C8-2 constrains the age of the archeology found, to the south, in C8-3/AH3 of 2006-2011, and, to the north, in AH3 of 19081909, well supported? And, archeologically, are C8-3/AH3 of 2006-2011 and AH3 of 1908-1909 one and the same thing? That these questions must be asked derives from several observations.

Firstly, the three C8 lenses are never observed together in the same section, and it is only southward of N 120 that C8-2 is seen overlying C8-3. Northward of N 120, when $\mathrm{C} 8-2$ is present, $\mathrm{C} 8-3 / \mathrm{AH} 3$ is not.

Secondly, C8-1 contains redeposited C8-2 humic pellets, C8-2 itself is a bioturbated soil, and, over most of their extent, the lenses upon which the correlation is based are "stretched," i.e., reworked. Thus, whether the vertical succession of three different lenses within the $\mathrm{C} 8$ subunit corresponds to a true stratigraphy needs to be demonstrated rather than assumed. This is the more so because, northward along the crosssections, the internal differentiation of the $\mathrm{C} 8$ subunit into three distinct lenses is no longer observed, while C8 itself, $>15 \mathrm{~cm}$-thick at N 120, becomes $\leq 5 \mathrm{~cm}$-thick beyond N 127 (Fig. 4).

Thirdly, the implications of the southward telescoping of C8 need to be assessed bearing in mind the significant slope of the stratification. At $\mathrm{N} \mathrm{129}$, the top of C8 is at an elevation of $99.2 \mathrm{~m}$, but at N 119 it is at $98.6 \mathrm{~m}$, i.e., there is a $\mathrm{N} \rightarrow \mathrm{S}$ slope of $6 \%$. Along the other axis, at N 126, the southern edge of Haesaerts's 1993 trench, the slope is twice that from west to east, $1 \mathrm{~m}$ over $8 \mathrm{~m}$, i.e., $12 \%$ (Fig. $3 \mathrm{~d}$ ).

Fourthly, C8-1 has not been dated and, therefore, only the single result for C7-1 provides an unambiguous terminus ante quem for the C8 package: $34,570 /+410 /-330$ BP (GrA-38250; 39,531-38,650 cal BP). This result is in correspondence with a previously unrecognized archeological horizon, AH3ab, whose existence within the 
C7-1 lens (Fig. 4) is for the first time mentioned by Nigst et al. (2014). In conjunction with the result for D1-top, this terminus allows us to constrain the archeological contents of $\mathrm{C} 8$ and $\mathrm{AH} 3$ across the entire site. However, it does so for a time spanbetween $38.6 \mathrm{ka}$ (the youngest possible age of C7-1) and $47.4 \mathrm{ka}$ (the oldest possible age of D1-top) that is much broader than Nigst et al.'s.

If C8-2 is indeed an in situ paleosoil, then there is no question that C8-3 must predate it. If the dated charcoal samples from $\mathrm{C} 8-2$ are also in situ, then there is no question that the accumulation of C8-3 predates those samples' ages. However, C8-2 (a) is found in situ only "at two spots, from N 117 to N 121 and from N 124 to N 126, respectively, with a sharp upper limit," (b) "in other spots, especially from N 127 to N 130, it is passing into semi-continuous lenses, often duplicated," and (c) features a "strongly bioturbated lower boundary," even where found in situ (Nigst et al. 2014). Combined with the slope of the stratification, these characteristics of the C8-2 lens make it possible that inherited charcoal material, acquired through progradation, be found therein. Since C8-3
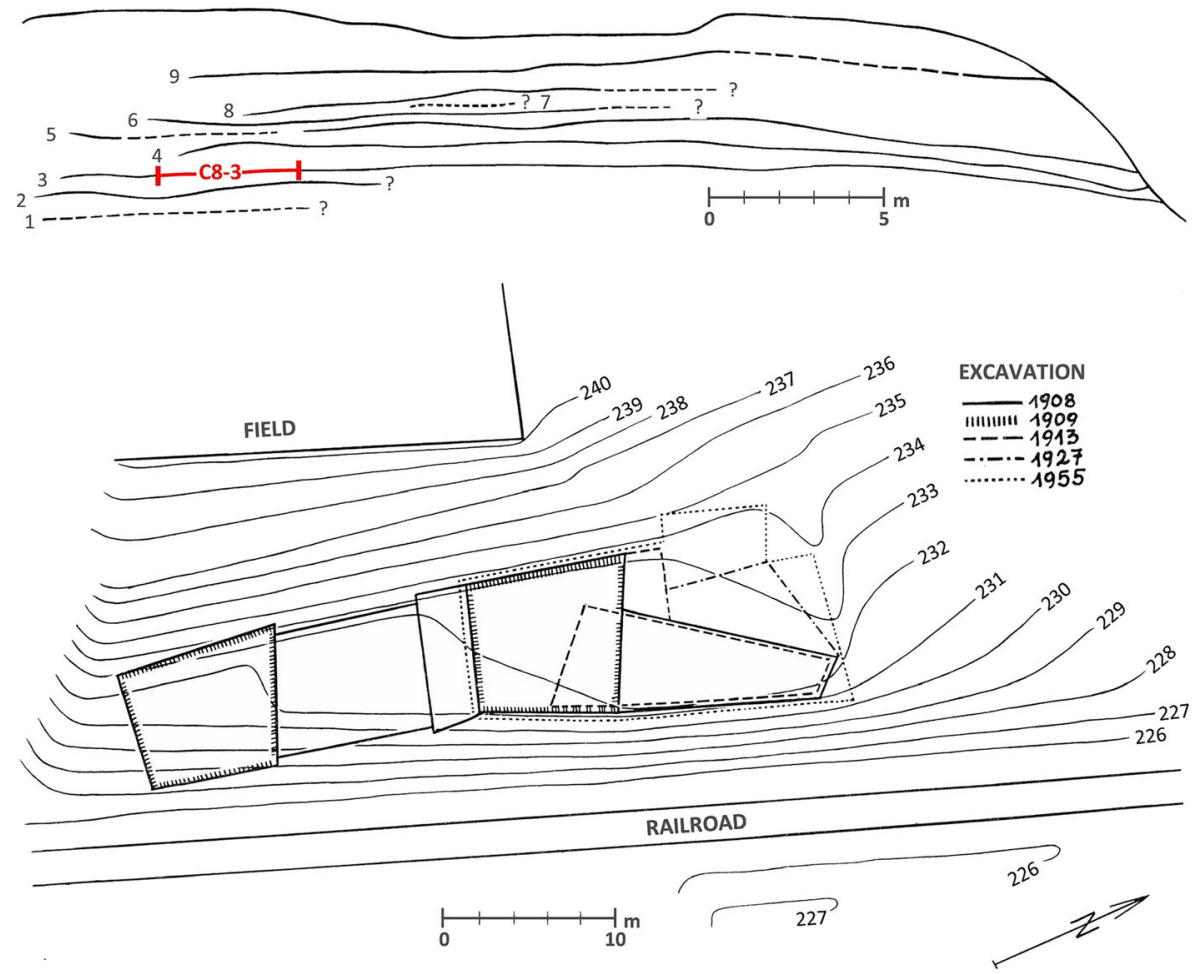

Fig. 5 The horizontal extent of Bayer's and Felgenhaeur's AH3. Bottom: layout of Willendorf II's “main excavation trench" (Hauptgrabungsfeld) with the delimitation of the areas affected by the different field seasons. Top: schematic stratigraphic profile illustrating the extent of the different archeological horizons recognized 19081955 along the trench's west wall; the red line and bars denote the approximate extent and boundaries of the C8-3 lens as identified 2006-2011. After Felgenhauer (1956-1959, Figs. 60, 82), modified 


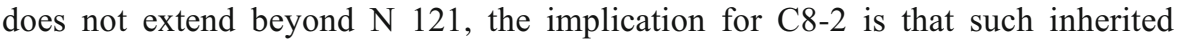
charcoal could derive from areas of $\mathrm{C} 9$ or the top of D1 exposed further upslope-in which case the dates for $\mathrm{C} 8-2$ would represent a terminus ante, not post quem, for the archeology in C8-3.

More to the point, Nigst et al.'s (2014) line of reasoning seems to be as follows: (a) C8-3 does not exist in the northern half of the excavated area, and (b) in the southern part of the site (zones 03 and 04 of the 2006-2011 excavations; Fig. 3d), C8-3 was the archeologically fertile lens of subunit C8; therefore, one can conclude that (c) the AH3 artifacts from 1908 to 1909 must come from the sector, southward of N 120, where the C8-3 lens was present, and (d) both the new and the old "AH3" artifact collections are chronologically bounded by the D1-top/C8-2 dating sandwich.

The fundamental flaw we perceive in this argument is that nothing in the evidence warrants the assumption that the deposit from where the 1908-1909 AH3 artifacts came is the strict stratigraphic equivalent of the C8-3 lens. Indeed, two features of the site's layout prove that the opposite is true. Firstly, Felgenhauer's (1956-1959, Fig. 75) rendering of the horizontal extent reached by the 1908-1909 excavations explicitly shows that the latter's "AH3" extended to N 126 of the new grid, $\geq 6 \mathrm{~m}$ beyond the northern boundary of the C8-3 lens as defined in 2006-2011 (Fig. 3a). Secondly, Nigst et al.'s (2008b) discovery, in storage at the Vienna museum, of a box with a hundred artefacts from Felgenhauer's 1955 excavation of "AH3" shows that the latter extended even further to the north, possibly even beyond Haesaerts's 1993 trench - as otherwise demonstrated by Felgenhauer's (1956-1959, Fig. 82) overall stratigraphic scheme, in which he merges his own observations with those from previous field seasons (Fig. 5). In short, the C8-3 lens only exists in about half of the area, at most, over which AH3 was identified in 1908-1909, and in less than a fifth of the total area in which AH3 was present if the 1955 excavations are also considered.

Felgenhauer's plans also make it clear that the 1908-1909 excavation encountered charcoal-rich and artifact-bearing lenses, even though poor ("almost sterile;" our emphasis), in intermediate stratigraphic position between $\mathrm{AH} 3$ and overlying AH4. When reporting on the typology of Willendorf II's stratigraphic sequence, Felgenhauer (1956-1959: 55) states that these so-called Intercalarschichte yielded no more than a couple of artifacts "worthy of mention:" an atypical fragment and a flake possibly used as a scraper. These intermediate lenses may well correspond to the newly designated $\mathrm{C} 7-1 / \mathrm{AH} 3 \mathrm{ab}$ horizon. If so, this horizon, identified at $\mathrm{N}$ 120 of the new grid (Fig. 4), would have extended, based on Felgenhauer's (19561959, Fig. 75) plans, even beyond N 126, the northern boundary of the 1908-1909 trench (Fig. 3a, e).

We could find no information on the distance vertically separating AH3 from such Intercalarschichte, and it remains possible that they correspond to lenses found higher up, between $\mathrm{AH} 3 \mathrm{ab}$ and $\mathrm{AH} 4$, that are not represented, or visible, in the sections described by Nigst et al. (2014). Be it as it may, these Intercalarschichte illustrate that the stratigraphy of Willendorf II was rather more complex, and included a lot more lateral variation, than intimated by the "Archeological Horizon" system under which it was organized by the original excavators. For instance, Intercalarschichte also existed between $\mathrm{AH} 2$ and $\mathrm{AH} 3$, 
while Felgenhauer's (1956-1959) descriptions of AH3 and AH4 (p. 91-92) ${ }^{1}$ leave little doubt that each of these "layers" or "horizons" corresponds to the grouping

\begin{abstract}
${ }^{1}$ Kulturschichte 3 (Abb. 75): Ausgegraben in den Jahren 1908 und 1909, aufgeschlossen im Jahre 1955. Geostratigraphische Position in dem Schichtpaket von Lößlehmen und grauen Schichten und zwar als unterste der nun folgenden Schichten. Höhenlage 230,80 m über NN, 4,90 m über der Bahnstrasse und $1,20 \mathrm{~m}$ über Schicht 2. Ebenfalls nur im Südteil des Hauptgrabungsfeldes freigelegt, im Umfange von ca.20 m Länge und durchschnittlich 8 m Breite, konnte ihre Ausdehnung aber durch den Profilgraben 1955 auf das gesamte Grabungsfeld festgestellt werden. Ihre mittlere Mächtigkeit beträgt ca.18 cm. Im gesamten Aufschluß ist sie fast durchwegs-mit Ausnhame der Südwestecke-gut ausgeprägt, in der Färbung kenntlich. Stellenweise kommen kleinere Stellen dichter Holzkohle (bis zu $5 \mathrm{~cm}$ stark) vor, die von Obermaier als „Herde"gedeutet wurden. Über die ganze Schicht sind Gesteinstrümmer verstreut. Die Schicht fällt nach Osten und streicht nach Süden. Über ihr und unter Schicht 4 sind wiederum einzelne kleinere Straten, teilweise mit Kohlenanreicherungen festgestellt worden.
\end{abstract}

Archeological Horizon 3 (Fig. 75): Excavated in the years 1908 and 1909, and again in the year 1955. Geostratigraphical position: at the bottom of the package of lehm and gray layers that overlie it. Elevation: $230.80 \mathrm{~m}$ above sea level, $4.90 \mathrm{~m}$ above the railroad, and $1.20 \mathrm{~m}$ above layer 2 . Also found only in the southern part of the main excavation trench, in an area approximately $20 \mathrm{~m}$ in length and $8 \mathrm{~m}$ in width, its extent over the entire excavation area could however be determined by way of the 1955 profile. Its average thickness amounted to ca.18 cm. Across its total exposed area-the southwest corner excepted-it almost always appears quite distinctively, recognizable by coloration. In places, small, dense, up to 5-cm-thick concentrations of charcoal occur, which Obermaier interpreted as "hearths." Scattered rock debris are found across the entire layer. The layer dips to east and strikes to south. Above it and below layer 4, small, separate, sometimes charcoal-rich strata could be observed.

Kulturschichte 4 (Abb. 76): Ausgegraben während der Grabungen der Jahre 1908, 1909, 1913, 1927 und 1955, ist sie die mittlere der in den Schwemmlehmen liegenden Kulturschichten. Ihre absolute Höhe beträgt 231,15 m, d. i.,5,20 m über dem Bahnniveau und 0,35 m über Schichte 3. Sie ist nach der Grabung 1955 im gesamten Hauptgrabungsfeld und somit in ihrer ganzen Nord-Süd-Erstreckung abgedeckt und durch die Tiefengrabung 1913/I auch noch westlich am Berghang nachgewiesen. Sie fällt gleichmäßig von West nach Ost und streicht fast horizontal, sich nur im Nordteil etwas stärker gegen Nord senkend.Stellenweise zeigt sie mäßige Aufspaltung in einzelne Äste. In ihrer Lage is nicht plan, sondern ziemlich stark gewürgt und teilweise aufgewölbt, wodurch sie sich den Schichten 3 und 5 stellenweise sehr unterschiedlich nähert. Ihre Mächtigkeit beträgt dort, wo sie tatsächlich als regelrechte Kulturschichte ausgeprägt erscheint, im Mittel $10 \mathrm{~cm}$. Am besten ausgeprägt ist die Schichte im Zentrum des Aufschlusses und in der Südwestecke, wo sie sich nach Obermaier eigentlich ,, als ein grosser, gleichmäßiger Feuerplatz "von schwarzbrauner Farbe, kompakt, speckig mit zahlreichen Holzkohlen erweist. Die Zwischenflächen sind eigentlich nur als Fundhorizont durch Silex-abspliße, Knochen und Kohleflocken ausgewiesen. Typen finden sich nur im Süden und Norden. Während der Grabung 1955 konnte im Nordteil des Grabungsfeldes ein Herd aufgedeckt werden, der aus einer flachen, Herdgrube bestand, welche mit Holzkohlen und Aschensubstanz gefüllt war. Am Rande der Herdgrube lagen sternförmig 6 im Durchshcnitt $2 \mathrm{~cm}$ starke, verkohlte Holzstücke, von denen 4 an ihrem äusseren Ende in aufrecht stehenden Astgabeln lagen. Auch diese waren verkholt.

Archeological Horizon 4 (Fig. 76): Excavated during the excavations of the years 1908, 1909, 1913, 1927, and 1955, it is, among the archeological horizons contained in the colluvial lehm, the middle one. Its elevation is $231.15 \mathrm{~m}$, i.e., $5.20 \mathrm{~m}$ above the railway level and $0.35 \mathrm{~m}$ above layer 3 . With the 1955 excavation, the layer is now seen to exist over the whole of the main excavation trench and thus across its entire north-south extent, and by way of the 1913/I deep sounding could also be observed to the West, into the slope. It dipped evenly from west to east and struck almost horizontally; only in the northern part did it sink somewhat more sharply to the north. In places, it featured moderate splitting into separate branches. The layer is not level; in parts, it is quite strongly choked, or else bulging, whereby the distance separating it from layers 3 and 5 is highly variable. Where it does appear as a true archeological horizon, its thickness is, on average, $10 \mathrm{~cm}$. The layer is best defined in the central part of the exposed area, and in the southwest corner, where it appeared to Obermaier "as a large, regular hearth" of black-brown color, compact, greasy, with numerous charcoals. The intermediate surfaces can only be identified as a find horizon through their flint chippage, bones, and charcoal flecks. Typologically defined items are found only in the south and north. During the 1995 excavations, a hearth could be revealed in the northern part of the excavation area; it consisted of a flatbottomed pit filled with charcoal and an ashy substance. Around the hearth, there were six, on average $2 \mathrm{~cm}-$ thick, charred wood fragments forming a star-shaped arrangement, of which four lay on forked wood branches stuck at the feature's outer rim. These were also carbonized. 


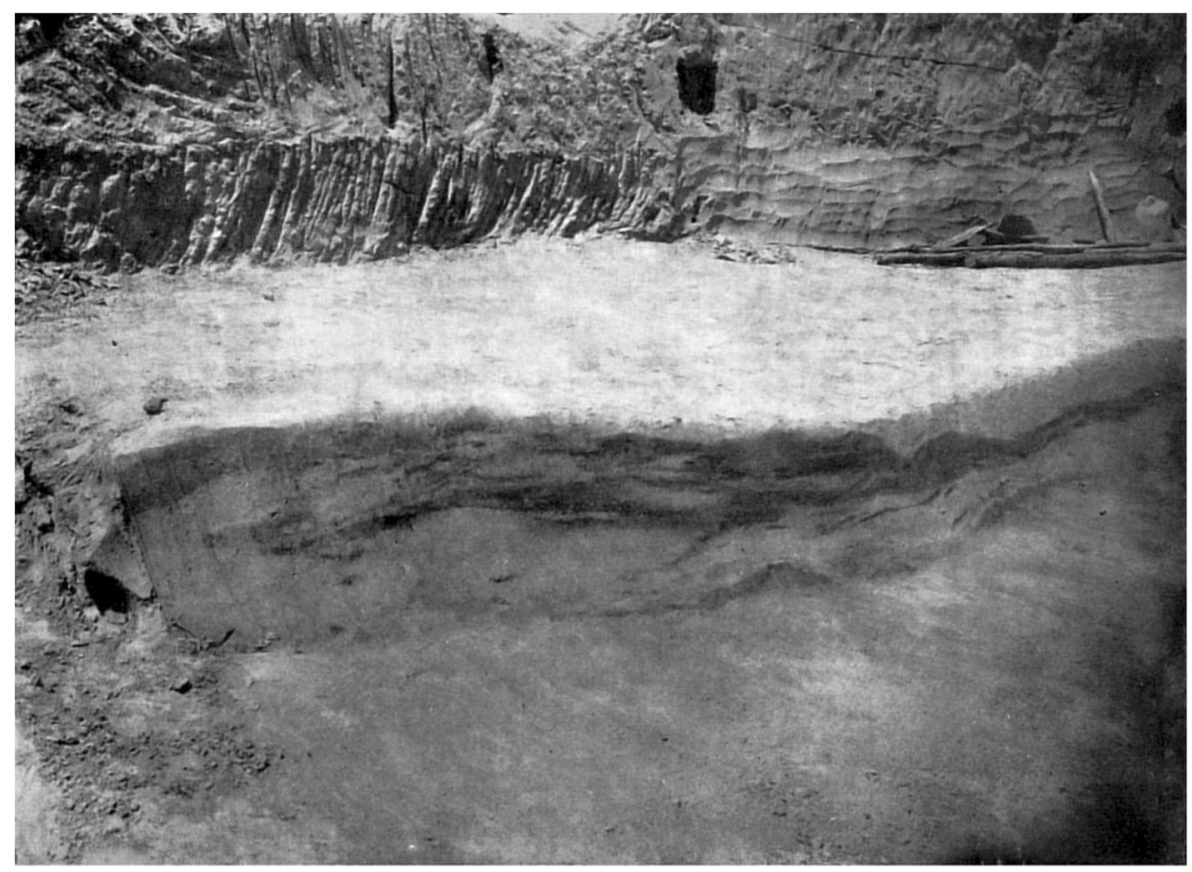

Fig. 6 AH4 in cross-section view.The image was taken in 1927, in the northern part of Willendorf II's "main excavation trench" (Hauptgrabungsfeld) (see Figs. 4 and6 for the position of the area excavated in 1927 relative to Felgenhauer's, Haesaerts's and Nigst et al.'s trenches). After Felgenhauer (1956-1959, Fig. 85)

together of lenses (and their finds) that, despite horizontal and vertical discontinuity, were close enough to be considered a single "unit."

AH3 itself is described as discontinuous (stellenweiseunterbrechen; Felgenhauer 1956-1959, Fig. 75), but the greater detail provided for the layout of overlying AH4 is more telling: not level; quite irregular in thickness and vertical separation from layers 3 (below) and 5 (above); often formed of separate lenses. Felgenhauer's (1956-1959, Fig. 85) photo of a profile view of AH4 in the process of excavation, as seen during the 1927 field season (Fig. 6) - i.e., as observed at the northern end of the main excavation trench, northward of Haesaerts's - clearly shows how Willendorf II's "horizons" corresponded to rather thick successions of dark lenses, each representing either separate moments of a palimpsest accumulation or the stretching/telescoping/reworking of a single such moment. In this part of the site, as seen in the walls of Haesaerts's trench, "AH3" presented a similar configuration, with the $\mathrm{C} 7$ and $\mathrm{C} 8$ subunits coming into direct contact to form a thick, darker band of sediments (Fig. 2). Even if, here, Haesaerts et al. (1996) and Nigst et al. (2008a) could nonetheless differentiate an internal stratigraphy, there can be little doubt that Bayer and Felgenhauer would have considered that band as forming a single "archeological horizon."

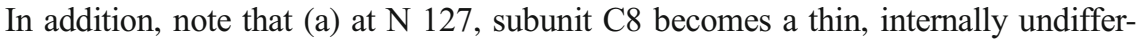
entiated lens separated by no more than $10 \mathrm{~cm}$ from the C7-1 lens in which, a few meters to the south, AH3ab has been defined (Fig. 4), (b) the combined thickness of the C7-C8 subunits decreases to the north and is $<20 \mathrm{~cm}$ northward of $\mathrm{N} \mathrm{124}$, and (c) 
Felgenhauer (1956-1959, p. 92) describes AH3 as $18 \mathrm{~cm}$-thick on average (which implies that, in places, it was thicker). It follows from these observations that, in the northern parts of the 1908-1909 trench, the deposit excavated as "AH3" must have included material that came indeed from both the $\mathrm{C} 8$ and the $\mathrm{C} 7$ lenses-i.e., from $\mathrm{AH} 3 \mathrm{ab}$ or (if they are not the same thing) the Intercalarschichte between $\mathrm{AH} 3$ and AH4 (not excluding other, similar lenses that the 1908-1909 excavators may not have recognized, or formally differentiated).

The available evidence shows, therefore, that, when the totality of its spatial extent is considered, "AH3" of the 1908-1909 excavations must have been the equivalent of the whole of the C7-C8 stratigraphic subunits of 2006-2011. Beyond the new grid's North 120 line - an area that includes the 1955 trench and more than half of the 1908-1909 trench-"AH3" corresponds to material excavated from parts of the site where, archeologically speaking, it must stand for "AH3+AH3ab." Put another way, the "1908-1909 AH3 artifact assemblage" does not come solely from the C8-3 lens, and, more to the point, includes material derived from geological units that radiocarbon places some five millennia apart (see below).

This spatial evidence in any case shows that the minimum age derived from the dating of samples contained in the C8-2 lens only applies to the parts of the "AH3" assemblage that can be securely provenanced to the underlying C8-3 lens. This condition is satisfied by the collection from 2006-2011, but not by the collections from 1908-1909 and 1955. This earlier work extended into areas where the $\mathrm{C} 8$ subunit could not be subdivided and in which the finds may well have been made in the lateral equivalent of the C8-1 lens or in subunit C7. For such finds, the dates for C8-2 would represent a maximum, not a minimum age of deposition. Can we exclude that the few Early Aurignacian diagnostics from the 1908-1909 excavation come from areas of the trench where "AH3" means C8-1, C7-1, or AH3ab? The artifacts collected during the 1908-1909 fieldwork were not piece-plotted and were not even provenanced to smaller sectors or grid units. Therefore, the answer is: No, we cannot.

In short, even if valid, in and of themselves Nigst et al.'s (2014) stratigraphic interpretation of Willendorf II and the correlations upon which it is based do not answer two key questions. The first question is whether the charcoal from C8-2 that provides a terminus ante quem for $\mathrm{C} 8-3$ is in situ-which is reasonable, perhaps even likely, but remains to be verified. The second question is whether the 1908-1909 artifact collection labeled "AH3" comes entirely from the C8-3 lens as defined in 2006-2011-which is unreasonable, and indeed contradicted by all published evidence.

\section{AH3: The Dating}

As Nigst et al. (2014) also discuss at length, these issues of correlation are necessarily entangled with issues of reliability: To what extent can the dating results we have for Willendorf II (Fig. 4) be deemed accurate?

Looking at the three homogenized samples from D1-top, C8-2, and C4-2 used in the cross-dating experiment that Nigst et al. (2014) report on, and using the sample 
significance tests incorporated in the Calib 7 software package (Ward and Wilson 1978; Stuiver and Reimer 1993), the following conclusions are apparent:

- The ABA (acid-base-acid) pre-treatment applied at the Oxford laboratory was in two cases (the samples from C4-2 and D1-top) insufficient to completely decontaminate the fraction processed there.

- In two other cases (the samples from C4-2 and C8-2), the fraction processed with the ABOx-SC method at Oxford yielded statistically indistinguishable results to the fraction dated at Groningen with ABA.

- In the third case (the sample from D1-top), the fraction ABOx-ed at Oxford yielded a result slightly older $(43,200 \pm 900 \mathrm{BP}$; OxA-25836) than the fraction treated with $\mathrm{ABA}$ at Groningen $(40,870 /+480 /-400 \mathrm{BP}$; GrA-52417).

For samples dating to $<40 \mathrm{ka} \mathrm{BP}$ (uncalibrated), no a priori reason therefore exists to call into question the accuracy of the Groningen results for Willendorf II. Much the same is acknowledged by Nigst et al. (Nigst et al. 2014, SI, section 3.3), whose take on this issue is that "the dating results of the D1-D2 samples pre-treated with ABA vs. the ones pre-treated with $\mathrm{ABOx}-\mathrm{SC}$ seem to confirm the need for the latter pretreatment of samples older than 40 ka BP" (our emphasis).

Despite this evidence, it remains possible that the result initially obtained for C8 in the 1981-1993 trench $(34,100 /+1200 /-1000 \mathrm{BP} ; \mathrm{GrN}-11192)$ is anomalously young because of the "uncleaned" nature of the bulk charcoal sample used, as claimed by Nigst et al. (2014). This is a legitimate interpretation, but legitimate is not the same as correct. Indeed, (a) other pairs of AMS (GrA) and conventional ( $\mathrm{GrN}$ ) Groningen dates for Willendorf II are statistically identical, and (b) the same applies to pairs of GrN and OxA results, namely where Unit D is concerned. This includes two 1980 samples collected and processed in the same manner as GrN-11192, both of which yielded the same age as 2006-2011 samples from the same units that were OxA-dated: for D1middle, 39,500/+1500/- $1200 \mathrm{BP}(\mathrm{GrN}-11190)$ and 39,980 $\pm 350 \mathrm{BP}(\mathrm{OxA}-17398)$; for D1-lower, 41,700/+3700/-2500 BP (GrN-11195) and 41,800 $\pm 400 \mathrm{BP}$ (OxA17400).

That these Unit D results may well be minimum ages only is indicated by the ABOx-SC result for D1-top $(43,200 \pm 900 \mathrm{BP}$; OxA-25836). That the underestimation affected the two laboratories and the two levels in similar manner suggests, however, that the cause lies in the insufficiency of ABA to remove all contamination, not in preparation-specific differences opposing the 1980 samples to the 2006 ones. If so, i.e., if the "cleanliness," or lack thereof, of the 1980 samples is in fact not an issue, then whether the GrN-11192 result of ca.34.1 ka uncal BP for C8 can be rejected on technical grounds becomes unclear to us. It might be possible to reject it on the grounds that it is stratigraphically anomalous. Such rejection, however, would entail an evident circularity of reasoning, as it would assume, rather than show, that the charcoal content of subunit C8 of the 1981-1993 trench is chronologically homogeneous.

In conclusion, (a) in the 1981-1993 trench, C8 appears reduced to a thin lens that effectively merges with $\mathrm{C} 7$ to form a single, internally undifferentiated package (Fig. 2); (b) at N 120, the date obtained for C7 on a 2007 sample $(34,570 /+410 /-330$ BP; GrA- 

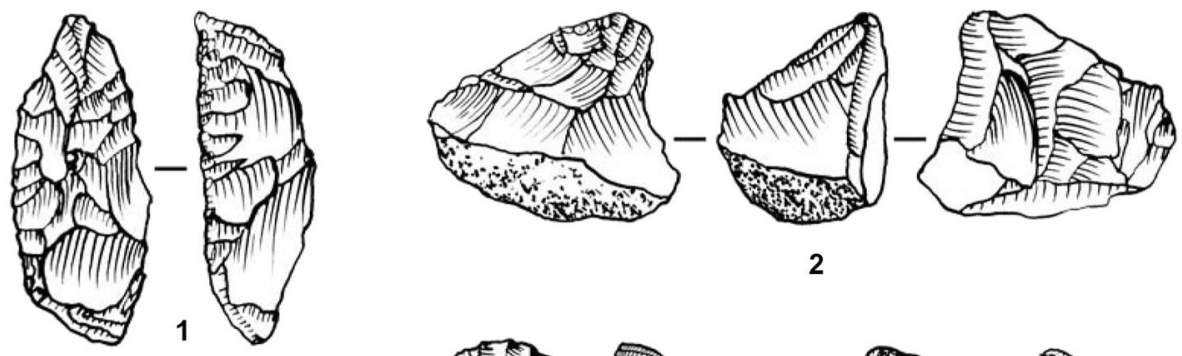

2
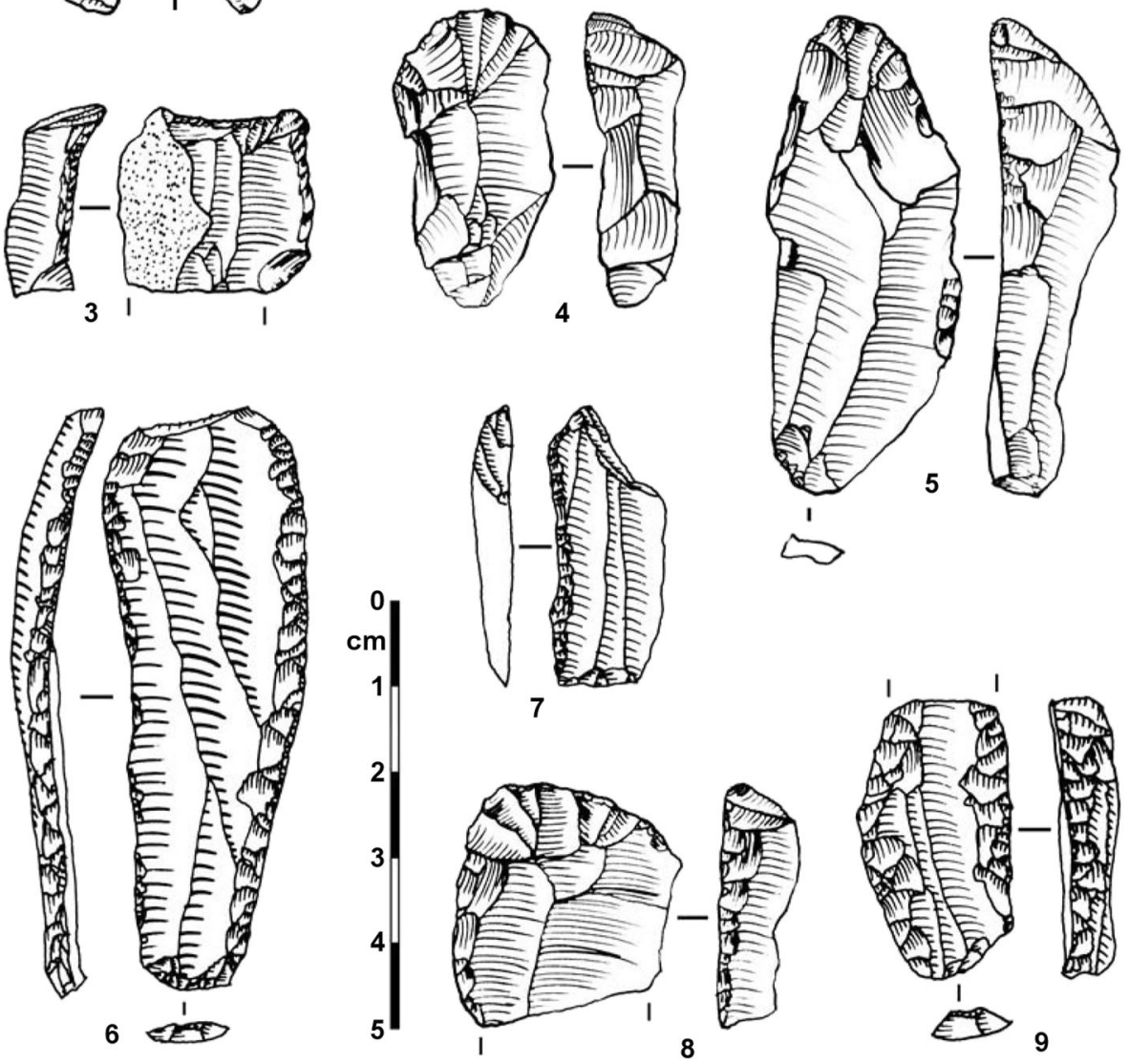

Fig. 7 Aurignacian diagnostics in the old AH3 collection (after Haesaerts and Teyssandier 2003). 1-3: nosed endscrapers; 4-5: carinated cores; 6, 9: retouched blades; 7: burin on truncation; 8: simple endscraper. These classifications are as originally published, but note that the classification of nos. $2-3$ is questionable. The classification of no. 1 is warranted by the characteristic marks of the setting-up of a carinated/nosed front observed in hands-on examination of the object. No. 6 features a spurred, lipped butt, and other attributes of soft-hammer extraction

38250 ) is statistically the same as, $10 \mathrm{~m}$ further to the north, GrN-11192; and (c) no technical grounds exist to question the validity of the Groningen results for Willendorf II that come from samples younger than $40 \mathrm{ka} \mathrm{BP}$ (uncalibrated). Under these premises, it is therefore legitimate to consider that, together, GrN-11192 and GrA-38250 support extending to $38.6 \mathrm{ka}$ - thereby overlapping with the Early Aurignacian as dated in Southwest France and elsewhere- the younger limit of the time window potentially 
represented by the stratigraphically heterogeneous 1908-1909 “AH3” artifact assemblage.

\section{AH3: The Old Collections}

The contextual information reviewed above leads one to suspect that the stratigraphically heterogeneous AH3 collection from 1908 to 1909 must also be archeologically heterogeneous. We will now assess whether such is indeed the case by considering the technological and typological composition of its stone tools.

The discovery in the basement of the Natural History Museum, in Vienna (Nigst 2004; Nigst et al. 2008a, b; Nigst and Haesaerts 2012), of a wooden box from the 1908-1909 excavations containing some 450 lithics, enriched the collection from AH3. However, this new material is mostly undiagnostic and therefore needs not be considered here. The old AH3 collection described by Felgenhauer (1956-1959) is made up of 48 pieces, among which 22 retouched tools. Despite its small size, all past hands-on assessments of this collection, including typological (Felgenhauer 1956-1959; Broglio and Laplace 1966; Hahn 1977) and typo-technological analyses (Haesaerts and Teyssandier 2003; Teyssandier 2007; Nigst and Haesaerts 2012), have agreed that it includes items of undeniable Aurignacian affinities. Five carinated cores and three retouched blades, one of which bearing the characteristic Aurignacian retouch, support this position (Fig. 7). They are consistent with the Early Aurignacian also from a stratigraphic point of view, as the overlying AH4 horizon (a) features characteristic Evolved Aurignacian bladelets with a twisted profile, reflecting the use of carinated/nosed cores, and (b) is reliably dated to the corresponding chrono-stratigraphic slot of 37-35 ka.

Nigst et al. (2014) assume that the old, AH3-labeled collection is homogeneous, i.e., that it comes from a single stratigraphic unit and was produced during a single period of

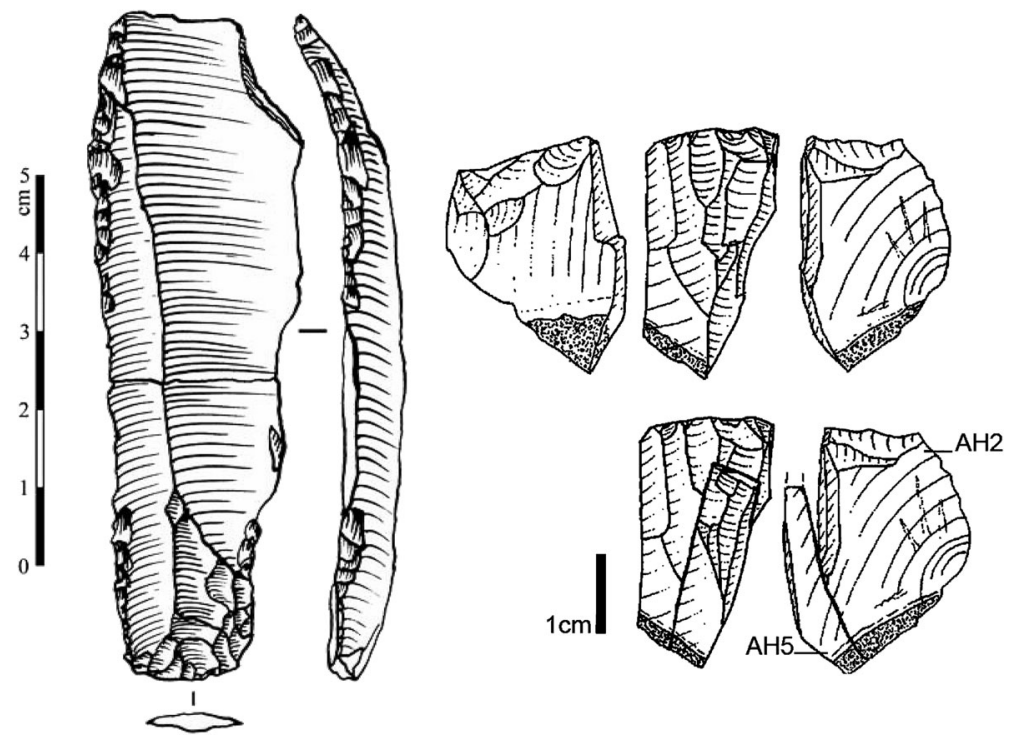

Fig. 8 Willendorf II, old AH2 collection. Left: soft-hammer blade (after Teyssandier 2007). Right: refit between an AH5 bladelet and an AH2 core (after Moreau 2012) 
occupation - that indicated by the Aurignacian diagnostics. As pointed out above, that cannot be the case. In addition, several lines of evidence support the likelihood that material abandoned at the site in the context of earlier, non-Aurignacian occupations exists among the old "AH3" collection.

The lower sequence of Willendorf II, AH1-to-AH3, is remarkable for the very small number of finds. For the old excavations, Nigst et al. (2008a) report a lithic density of one to two items $/ \mathrm{m}^{2}$, much the same as in the new ones, and that the finds "seem to have been deposited in concentrations with very few or no artefacts outside." This low-density, patchy pattern is consistent with the material having been syn-depositionally scattered along the local $\mathrm{NW} \rightarrow \mathrm{SE}$ slope, through run-off and other surface dynamics, and to have ended-up in residualization pockets potentially containing a mix of items with different origins - to be expected in periods of low, or nil, sediment accumulation such as those during which the humic horizons comprised in the $\mathrm{C} 8$ and $\mathrm{C} 7$ subunits formed.

Another cause for concern resides in the fact that the AH3 collection from 19081909 contains items that are clearly out of place in an Early Aurignacian context. Following Nigst and Haesaerts (Nigst and Haesaerts 2012, Table 2), AH3 would contain two sidescrapers and 12 "laterally retouched blanks." Among the latter, several could also correspond, based on the illustrations supplied, to sidescraper fragments. As previously pointed out (Zilhão 2013), sidescrapers are a rare occurrence in Early Aurignacian assemblages. However, the percentage they represent in AH3 would be, if the classifications are valid, at least ten times higher than in the Early Aurignacian of e.g., Geissenklösterle, in Germany, or the Abri Pataud, in France.

Two other observations further show that the homogeneity of the 1908-1909 collections needs to be critically examined instead of assumed-and this for all the archeological horizons, not just for AH3. These observations concern AH2 (Fig. 8). The corresponding 1908-1909 assemblage includes (a) one soft-hammer blade that, in the technological context of the period (AH2 is a pre-Aurignacian horizon), feels clearly anomalous (Teyssandier 2007) and (b) more to the point, a bladelet core that has been refitted to a bladelet from the Gravettian in AH5 (Moreau 2012).

Besides the Early Aurignacian, which other technocomplex(es) could be represented in the old AH3 collection is impossible to ascertain. All that can be said is that (a) it contains nothing that, based on the definitions used here, might be considered indicative of the Protoaurignacian and (b) the presence of sidescrapers can be taken to suggest the Mousterian, or perhaps one of the regional "transitional," Early Upper Paleolithic entities, e.g., the Szeletian.

\section{AH3: The New Collections}

Let us first bear in mind what AH3 means in terms of the 2006-2011 work: an area of $8.66 \mathrm{~m}^{2}$ in which the C8-3 lens yielded a low-density assemblage madeup of 32 lithic artifacts and 23 faunal remains - the latter all $<20 \mathrm{~mm}$ and mostly burned (whether the burning is anthropogenic is unclear). The assignment of this small lithic assemblage to the Early Aurignacian is based on the bladelet production it would stand for: "the bladelets from $\mathrm{AH} 3$ demonstrate the presence of two bladelet production schemes, both suggesting a disassociation of blade and bladelet technology" (Nigst et al. 2014).

Such disassociation is indeed what one might expect to find in an Early Aurignacian context. However, the assemblages from Southwest France in which 


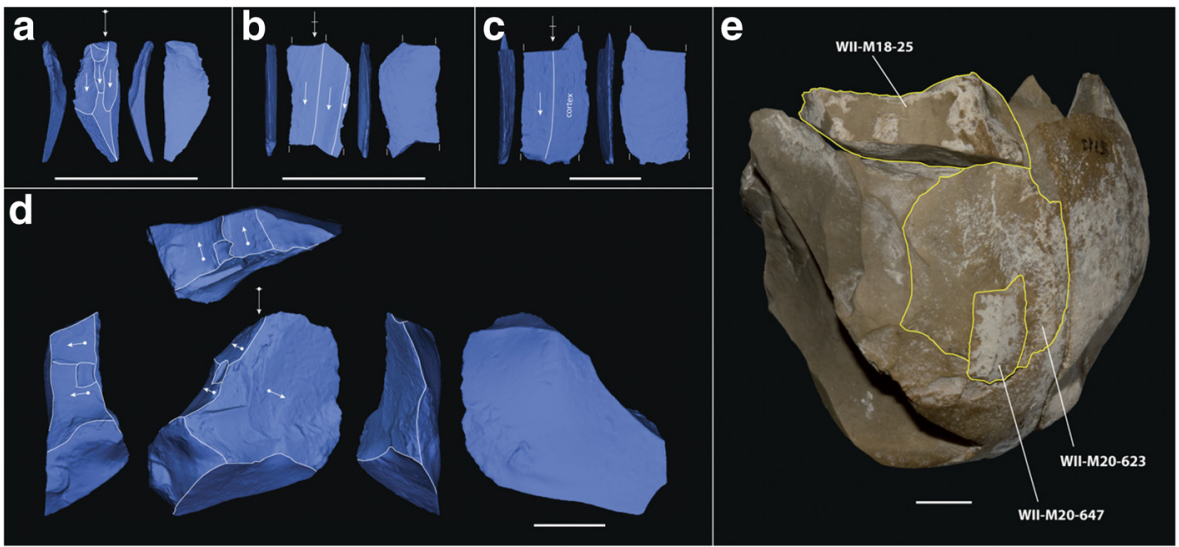

Fig. 9 3D models of lithic artifacts from AH 3 of Willendorf II (after Nigst et al. 2014). a Bladelet WII-L202492. b Bladelet fragment WII-M20-640. c Bladelet fragment WII-M20-647. d Core tablet WII-M18-25. e Refit unit linking lithics from 2006 to 2011 (yellow outline; WII-M18-25, WII-M20-623, WII-M20-647) with lithics from the old collection (no outline). See text in the "AH3: The New Collections" section for a technological discussion of this refit

the disassociation has been diagnosed are multiple, rich, and diversified. They include refits and thousands of blades, bladelets, cores, and byproducts. At Willendorf II, in contrast, the claim is based on an assemblage that contains zero blades, zero cores, and in which one (undescribed) core tablet and three bladelets are the only potentially technologically diagnostic items. On such a basis, it is simply not possible to arrive at Nigst et al.'s (2014) conclusions, as becomes even clearer when the bladelets' descriptions are examined in detail:

- WII-L20-2492 (Fig. 9a) is a complete blank (8.6 mm long, $3.2 \mathrm{~mm}$ wide, and $1.1 \mathrm{~mm}$ thick) with a linear platform, showing skewing to the right; it is argued that "bladelets of these technological features and shape are characteristic of a reduction sequence using carinated/nosed endscrapers as core;" such a type of reduction sequence can indeed produce blanks like the illustrated piece, but so can other types; a single, isolated piece is insufficient to warrant the diagnosis.

Table 3 Willendorf II culture-stratigraphy and dating. Alternative interpretations of the basal Upper Paleolithic sequence. Dates are uncalibrated radiocarbon ages Before Present

\begin{tabular}{|c|c|c|c|c|c|c|}
\hline \multirow[b]{3}{*}{$\begin{array}{l}\text { Geological } \\
\text { stratigraphy }\end{array}$} & \multicolumn{2}{|c|}{ Nigst et al. 2014} & \multicolumn{4}{|l|}{ This paper } \\
\hline & \multicolumn{2}{|c|}{ Whole area (1908-2011) } & \multicolumn{2}{|c|}{ 1908-1909 trench } & \multicolumn{2}{|l|}{1993 trench } \\
\hline & $\begin{array}{l}\text { Archeological } \\
\text { stratigraphy }\end{array}$ & $\begin{array}{l}\text { Dates } \\
\text { retained }\end{array}$ & $\begin{array}{l}\text { Archeological } \\
\text { stratigraphy }\end{array}$ & $\begin{array}{l}\text { Associated } \\
\text { dates }\end{array}$ & $\begin{array}{l}\text { Archeological } \\
\text { stratigraphy }\end{array}$ & $\begin{array}{l}\text { Associated } \\
\text { dates }\end{array}$ \\
\hline C7-1 & $\mathrm{AH} 3 \mathrm{ab}$ & - & \multirow{6}{*}{$\mathrm{AH} 3+\mathrm{AH} 3 \mathrm{ab}$} & \multirow{6}{*}{$34.6-39.0$} & \multirow[t]{3}{*}{$x_{0}$} & \multirow{3}{*}{-} \\
\hline $\mathrm{C} 7-2$ & - & - & & & & \\
\hline $\mathrm{C} 7-3$ & - & - & & & & \\
\hline $\mathrm{C} 8-1$ & - & - & & & \multirow{3}{*}{ AH3 } & \multirow{3}{*}{$34.1-38.9$} \\
\hline $\mathrm{C} 8-2$ & - & 39.0 & & & & \\
\hline $\mathrm{C} 8-3$ & AH3 & - & & & & \\
\hline $\mathrm{C} 9$ & - & - & \multirow[b]{2}{*}{-} & - & - & - \\
\hline D1 & - & $43.2,43.4$ & & $43.2,43.4$ & - & $39.5-41.7$ \\
\hline D2 & $\mathrm{AH} 2$ & 45.1 & $\mathrm{AH} 2$ & 45.1 & $\mathrm{AH} 2$ & - \\
\hline D3 & - & - & - & - & - & - \\
\hline
\end{tabular}


- WII-M20-640 (Fig. 9b) is a mesial fragment of a bladelet (8.1 mm long, $4.4 \mathrm{~mm}$ wide, and $0.9 \mathrm{~mm}$ thick) that might have been produced by any form of bladeletproducing reduction sequence.

- WII-M20-647 (Fig. 9c) is the mesial fragment of a blank (18.6 mm long, $9.8 \mathrm{~mm}$ wide, and $2.3 \mathrm{~mm}$ thick) whose dorsal side is cortical over about half of the preserved extent; it is argued that "the fact that it does not show any twisting or skewing and the rather wide width of $9.8 \mathrm{~mm}$ suggests that this bladelet was produced from a unidirectional prismatic core;" the truth is that this blank could have been obtained during the first stages of almost any reduction sequence; even though, metrically, WII-M20-647 fits the definition of a bladelet, it is not one in the technological sense; by the same token, its refitting onto a large cortical flake with two dorsal "bladelet" removals (Fig. 9e), from which it is concluded that "at least one more bladelet of the same morphology (compared to M20-647) was removed," is of no relevance for the assessment of the assemblage's affinities.

Indeed, "bladelets" such as those retrieved 2006-2011 in the C8-3 lens are not even sufficient to warrant the Upper Paleolithic-ness of the collection. Similar objects can be found in many Middle Paleolithic assemblages (e.g., Faivre 2012; Peresani and Centi Di Taranto 2013), and, per se, do not document the presence of a reduction system intent on obtaining bladelet blanks. Such morphological "bladelets" can for instance be accidentally produced during the preparation of the striking platforms of large discoid or Levallois cores.

The cortical "bladelet" and flake, plus another flake and the core tablet (Fig. 9d) from 2006-2011 could be refitted with a core and two flakes from the old AH3 collection. The graphic documentation makes it difficult to be certain, but we see in the core and the refit unit nothing to support the claim that this material documents a "special reduction sequence for producing large, straight bladelets" (Nigst et al. 2014). In fact, it is two flakes, one core tablet, one core, and two pieces of shatter that would fit well in any period of the Paleolithic: Lower, Middle, or Upper. The "AH3" stone tool assemblage recovered 2006-2011 in the C8-3 lens contains nothing diagnostic of the Aurignacian, in general, let alone the Early Aurignacian, in particular.

Since the 2006-2011 collection is entirely madeup of undiagnostic material, the only potential contribution of the refit set reproduced in Fig. 9 lies in the establishment of a clear link with the old collection. If the latter were homogeneous and of Early Aurignacian affinities, then the link would mean that (a) the dating constraints obtained for the new material would also apply to the old material, and (b) the cultural assignment of the old material would apply to the new material too. However, as we have shown, the "AH3" horizon of the old excavations must correspond to a thickness of humic deposits with charcoal and artifacts minimally encompassing two different occupations, AH3ab and AH3. In this context, the link between the 1908-1909 and 2006-2011 collections substantiated by the refit does not necessarily represent a link between two parts, excavated at different times, of one and the same original assemblage - much less that such putatively homogeneous single assemblage is Aurignacian (recall that the refit includes neither carinated pieces nor clear Upper Paleolithic blades or bladelets). 


\section{Conclusion}

In Table 3, we offer a summary of our reading of the archeological stratigraphy of Willendorf II's basal Upper Paleolithic levels and how it contrasts with Nigst et al.'s (2014). The key difference lies in that these authors extrapolate to the entire site, including the areas excavated in 1908-1909 and 1955, the validity of the archeological stratigraphy recognized in the limited area excavated 2006-2011, while we argue that the well-documented lateral variation of the stratigraphic succession and the lower resolution of the old excavations does not warrant the extrapolation.

As with the refit set linking AH2 to AH5 (Fig. 8), the refit set linking material from C8-3/AH3 of the 2006-2011 work and AH3 of 1908-1909 (Fig. 9) concerns a single initial raw-material volume. If the latter warrants the inference that both AH3-labeled collections derive from one and the same original, homogenous context, then the former must likewise warrant the opposite, i.e., that the assemblage integrity of the different AHs from 1908-1909 is compromised because (a) the Willendorf II sequence is heavily disturbed, or (b) the 1908-1909 collections underwent significant post-excavation mixing. Put another way, the refitting evidence for the 1908-1909 collections to be heterogeneous and unreliable is as strong as the refitting evidence for the AH3 artifacts from 1908-1909 to come entirely from the C8-3 lens. Or, depending on how one wishes to look at it, as weak. In our view, the latter is the parsimonious alternative.

Even if we accept that the dates for $\mathrm{C} 8 \mathrm{-} 2$ constrain the lithic assemblage from $\mathrm{AH} 3$ of 2006-2011, such dating could only be taken as "the age of the Early Aurignacian at Willendorf II" under the following premises: (a) the stratigraphic resolution of the 1908-1909 excavations was as detailed as that of the 2006-2011 excavations; and (b) the 1908-1909 artifact collection designated "AH3" includes no material retrieved above the C8-3 lens or in lateral equivalents of the newly recognized AH3ab horizon. But these premises are not warranted.

Nigst et al.'s (2014) key arguments are that (a) the two humic horizons at N 117-121 and N 124-126 are one and the same and (b) the charcoal from C8-2 used to constrain the age of the underlying C8-3/AH3 lens is in situ. As progress continues to be made in the understanding of Willendorf II's complex stratigraphy, these arguments may well be corroborated, and the dating to ca.43.5 ka of the stone tools found in the C8-3 lens thereby vindicated. But this does not mean that said tools can be deemed Aurignacian, and our brief review is sufficient to call into question any claim for such an attribution; not a single element of this 32-piece assemblage can be convincingly argued to be attributable to the Aurignacian or any other specific industry for that matter.

With regard to the old $\mathrm{AH} 3$ collection, present evidence is that it only serves to establish human presence in Lower Austria during the 47-37 ka interval. The parsimonious reading of that collection's stratigraphic and site-formation context is that (a) it subsumes finds made in at least the two archeological horizons identified 2006-2011 at the corresponding elevation, AH3 and AH3ab, and (b) as in Southwest France, everywhere else in western, central and southern Europe, and in southwest Asia, the old collection's few Early Aurignacian lithics date to the time range obtained for AH3ab (38.6-39.5 ka).

The notion that the Aurignacian is much earlier at Willendorf than everywhere else is inconsistent with the understanding of the Aurignacian as a technocomplex, and otherwise carries theoretically highly unlikely implications for the social organization 
and demography of Paleolithic hunter-gatherers. Our review shows that the notion is in any case empirically unsupported. Thus, associating the Early Aurignacian with modern humans in Lower Austria remains a legitimate inference for the 38-40 ka intervalbut not for a time prior to or around $43.5 \mathrm{ka}$.

Acknowledgements We thank Emmanuel Discamps, Erik Trinkaus, Francesco d'Errico, Lars Anderson, Will Banks, and Elise Tartar for fruitful discussions and comments on an earlier draft of the manuscript. As usual, any errors or omissions are our own.

\section{References}

Akazawa, T., Aoki, K., \& Bar-Yosef, O. (1998). Neandertals and modern humans in western Asia. New-York: Plenum Press.

Anderson, L., Bon, F., Bordes, J.-G., Pasquini, A., Slimak, L., \& Teyssandier, N. (2015). Relier des espaces, construire de nouveaux réseaux: aux origines du Protoaurignacien et des débuts du Paléolithique supérieur en Europe occidentale. In N. Naudinot, L. Meignen, D. Binder, \& G. Querré (Eds.), Les systèmes de mobilité de la Préhistoire au Moyen-Age (pp. 93-109). Antibes: ADPCA.

Bailey, S. E., \& Hublin, J.-J. (2005). Who made the Early Aurignacian? A reconsideration of the Brassempouy dental remains. Bulletins et Mémoires de la Société d'Anthropologie de Paris, 17(1-2), 1-7.

Banks, W. E., d'Errico, F., \& Zilhão, J. (2013a). Human-climate interaction during the Early Upper Paleolithic: testing the hypothesis of an adaptive shift between the Proto-Aurignacian and the Early Aurignacian. Journal of Human Evolution, 64, 39-55.

Banks, W. E., d'Errico, F., \& Zilhão, J. (2013b). Revisiting the chronology of the Proto-Aurignacian and the Early Aurignacian in Europe: a reply to Higham et al.'s comments on Banks et al. (2013). Journal of Human Evolution, 65, 810-817.

Bar-Yosef, O., \& Bordes, J.-G. (2010). Who were the makers of the Châtelperronian culture? Journal of Human Evolution, 59, 586-593.

Bayer, J. (1930). Die Venus II von Willendorf. Eiszeit und Urgeschichte. Leipzig, 7, 48-60.

Benazzi, S., Douka, K., Fornai, C., Bauer, C. C., Kullmer, O., Svoboda, J., Pap, I., Mallegni, F., Bayle, P., Coquerelle, M., Condemi, S., Ronchitelli, A., Harvati, K., \& Weber, G. W. (2011). Early dispersal of modern humans in Europe and implications for Neanderthal behaviour. Nature, 479, 525-529.

Bon, F. (2002). L'Aurignacien entre Mer et Océan. Réflexion sur l'unité des phases anciennes de l'Aurignacien dans le sud de la France. Paris: Société Préhistorique Française (Mémoire de la Société Préhistorique Française, XXIX).

Bordes, J.-G. (2006). News from the West: A reevaluation of the classical Aurignacian sequence of the Périgord. In O. Bar-Yosef \& J. Zilhão (Eds.), Towards a Definition of the Aurignacian (pp. 147-171). Lisboa: American School of Prehistoric Research/Instituto Português de Arqueologia (Trabalhos de Arqueologia, 45).

Bordes, J.-G., Bon, F., \& Le Brun-Ricalens, F. (2005). Le transport des matières premières lithiques à l'Aurignacien entre le nord et le sud de l'Aquitaine: faits attendus, faits nouveaux. In J. Jaubert \& M. Barbaza (Eds.), Territoires, déplacements, mobilités, échanges durant la préhistoire (pp. 185-198). Paris: CTHS.

Broglio, A., \& Laplace, G. (1966). Etudes de typologie analytique des complexes leptolithiques de l'Europe centrale. I. Les complexes aurignacoïdes de la Basse-Autriche. Rivista di Scienze Preistoriche, 21(1), 61121.

Clarke, D. (1978). Analytical archaeology (2nd ed.). London: Methuen.

Conard, N. J., \& Bolus, M. (2003). Radiocarbon dating the appearance of modern humans and timing of cultural innovations in Europe: new results and new challenges. Journal of Human Evolution, 44, 331371.

Conard, N. J., \& Bolus, M. (2008). Radiocarbon dating the late Middle Paleolithic and the Aurignacian of the Swabian Jura. Journal of Human Evolution, 55, 886-897.

Damblon, F., Haesaerts, P., \& Van der Plicht, J. (1996). New datings and considerations on the chronology of Upper Palaeolithic sites in the Great Eurasiatic Plain. Préhistoire Européenne, 9, 177-231. 
Delporte, H. (1984). Le grand abri de la Ferrassie. Fouilles 1968-1973. Paris: Laboratoire de paléontologie humaine et de préhistoire (Etudes quaternaires, 7).

Delporte, H. (1991). La séquence aurignacienne et périgordienne sur la base des travaux récents réalisés en Périgord. Bulletin de la Société Préhistorique Française, 88(8), 243-256.

Demars, P.-Y. (1992). L’Aurignacien ancien en Périgord: le problème du Protoaurignacien. Paléo, 4, 101-122.

Devièse, T., Karavanić, I., Comeskey Kubiak, D. C., Korlević, P., Hajdinjak, M., Radović, S., Procopio, N., Buckley, M., Pääbo, S., \& Higham, T. (2017). Direct dating of Neanderthal remains from the site of Vindija Cave and implications for the Middle to Upper Paleolithic transition. Proceedings of the National Academy of Sciences of the USA, 114(40), 10606-10611.

Discamps, E., Gravina, B., \& Teyssandier, N. (2015). In the eye of the beholder: contextual issues for Bayesian modelling at the Middle-to-Upper Palaeolithic transition. World Archaeology, 47, 601-621.

Dujardin, V. (2001). Sondages à la Quina aval (Gardes-le-Pontaroux, Charente, France). Antiquités Nationales, 33, 21-26.

Faivre, J.-P. (2012). A material anecdote but technical reality: bladelet and small blade production during the recent Middle Paleolithic at Combe-Grenal rock shelter. Lithic Technology, 37(1), 5-25.

Falcucci, A., Peresani, M., Roussel, M., Normand, Ch., \& Soressi M. (2016). What's the point? Retouched bladelet variability in the Protoaurignacian. Results from Fumane, Isturitz, and Les Cottés. Archaeological and Anthropological Sciences. https://doi.org/10.1007/s12520-016-0365-5 .

Féblot-Augustins, J. (2008). Paleolithic raw material provenance studies. In D. M. Pearsall (Ed.), Encyclopedia of archaeology (pp. 1187-1198). New York: Academic Press.

Felgenhauer, F. (1956-1959). Willendorf in der Wachau. Monographie der Paläolith-Fundstellen I-VII.Wien: Mitteilungen der Prähistorischen Kommission der Österreichischen Akademie der Wissenschaften VIIIIX.

Haesaerts, P. (1990). Nouvelles recherches au gisement de Willendorf (Basse-Autriche). Bulletin de l'institut royal des Sciences naturelles de Belgique. Sciences de la Terre, 60, 203-218.

Haesaerts, P., \&Teyssandier, N. (2003). The Early Upper Paleolithic occupation of Willendorf II (Lower Austria): a contribution to the chronostratigraphic and cultural context of the beginning of the Upper Paleolithic in central Europe. In J. Zilhão \& F. d'Errico (Eds.), The chronology of the Aurignacian and of the transitional technocomplexes. Dating, stratigraphies, cultural implications (pp. 133-151). Lisboa: Instituto Português de Arqueologia (Trabalhos de Arqueologia, 33).

Haesaerts, P., Damblon, F., Bachner, M., \& Trnka, G. (1996). Revised stratigraphy and chronology of the Willendorf II sequence (Lower Austria). Archaeologia Austriaca, 80, 25 -42.

Hahn, J. (1977). Aurignacien, das ältere Jungpaläolithikum in Mittel- und Osteuropa. Köln-Wien: Böhlau (Fundamenta; A 9).

Henry-Gambier, D., Maureille, B., \& White, R. (2004). Vestiges humains des niveaux de l'Aurignacien ancien du site de Brassempouy (Landes). Bulletins et Mémoires de la Société d'Anthropologie de Paris, 16(1-2), 49-87.

Higham, T. F. G., Brock, F., Peresani, M., Broglio, A., Wood, R., \& Douka, K. (2009). Problems with radiocarbon dating the Middle to Upper Palaeolithic transition in Italy. Quaternary Science Reviews, 28, 1257-1267.

Higham, T. F. G., Compton, T., Stringer, C., Jacobi, R., Shapiro, B., Trinkaus, E., Chandler, B., Gröning, F., Collins, C., Hillson, S., O’Higgins, P., Fitzgerald, C., \& Fagan, M. (2011). The earliest evidence for anatomically modern humans in northwestern Europe. Nature, 479, 521-524.

Higham, T. F. G., Basell, L., Jacobi, R. M., Wood, R., Bronk Ramsey, C., \& Conard, N. J. (2012). Testing models for the beginnings of the Aurignacian and the advent of figurative art and music: the radiocarbon chronology of Geißenklösterle. Journal of Human Evolution, 62, 664-676.

Higham, T. F. G., Douka, K., Wood, R., Bronk Ramsey, C., Brock, F., Basell, L., et al. (2014). The timing and spatio-temporal patterning of Neanderthal disappearance. Nature, 512, 306-309.

Hublin, J.-J. (2015). The modern human colonization of western Eurasia: when and where? Quaternary Science Reviews, 118, 194-210.

Jacobi, R. M. (1990). In Leaf-points and the British Early Upper Palaeolithic. In dans J. K. Kozłowski (Ed.), Feuilles de pierre (pp. 271-289). Liège:Université de Liège (ERAUL 42).

Julien, M., Baffier, D., \& Liolios, D. (2002). L'industrie osseuse. In B. Schmider (Ed.), L'Aurignacien de la grotte du Renne. Les fouilles d'André Leroi-Gourhan à Arcy-sur-Cure (Yonne) (pp. 217-250). Paris: Gallia Préhistoire (Supplément XXXIV).

Karavanić, I., \& Smith, F. H. (2014). Alternative interpretations of the Middle/Upper Paleolithic interface at Vindija cave (northwestern Croatia) in the context of central Europe and the Adriatic. Archaeology Ethnology \& Anthropology of Eurasia, 41(4), 11-20. 
Lazuén, T. (2012). European Neanderthal stone hunting weapons reveal complex behaviour long before the appearance of modern humans. Journal of Archaeological Science, 39, 2304-2311.

LeBrun-Ricalens, F. (2005). Reconnaissance d'un concept techno-cultural de l'Aurignacien ancien? Modalités, unités et variabilités des productions lamellaires du site d'Hui (Beauville, Lot-et-Garonne): significations et implications. In F. Le Brun-Ricalens (Ed.), Productions lamellaires attribuées à l'Aurignacien, chaînes opératoires et perspectives techno-culturelles (pp. 157-190). Luxembourg: MNHA (ArchéoLogiques, 1).

Liolios, D. (1999). Variabilité et caractéristiques du travail des matières osseuses au début de l'Aurignacien: approche technologique et économique. $\mathrm{PhD}$ : university Paris X-Nanterre.

Liolios, D. (2006). Reflections on the role of bone tools in the definition of the Early Aurignacian. In O. BarYosef \& J. Zilhão (Eds.), Towards a definition of the Aurignacian (pp. 37-51). Lisboa: American School of Prehistoric Research/Instituto Português de Arqueologia (Trabalhos de Arqueologia, 45).

Moreau, L. (2012). Le Gravettien d'Europe centrale revisité: mise au point et perspectives. L'Anthropologie, $116(5), 609-638$.

Moreau, L., Bostjan, O., Higham, T., Horvat, A., Pirkmajer, D., \& Turk, P. (2015). Reassessing the Aurignacian of Slovenia: techno-economic behaviour and direct dating of osseous projectile points. Journal of Human Evolution, 78, 158-180.

Müller, U. C., Pross, J., Tzedakis, P. C., Gamble, C., Kotthoff, U., Schmiedl, G., Wulf, S., \& Christanis, K. (2011). The role of climate in the spread of modern humans into Europe. Quaternary Science Reviews, 30, 273-279.

Nigst, P. R. (2004). "Neue" alte Funde aus Willendorf II, Schicht 3. Archäologie Osterreichs, 15(1), 23-25.

Nigst, P. R. (2006). The first modern humans in the Middle Danube Area? New evidence from Willendorf II (Eastern Austria). In N. J. Conard (Ed.), When Neanderthals and modern humans met (pp. 269-304). Tübingen: Kerns Verlag.

Nigst, P. R., \& Haesaerts, P. (2012). L'Aurignacien en Basse Autriche: résultats préliminaires de l'analyse technologique de la couche culturelle 3 de Willendorf II et ses implications pour la chronologie du Paléolithique supérieur ancien en Europe centrale. L'Anthropologie, 116, 575-608.

Nigst, P. R., Viola, B., Haesaerts, P., Blockley, S., Damblon, F., Franck, C., Fuchs, M., Götzinger, M., Hambach, U., Mallol, C., Moreau, L., Niven, L., Richards, M., Richter, D., Zöller, L., Trnka, G., \& Hublin, J.-J. (2008a). New research on the Aurignacian of central Europe: a first note on the 2006 fieldwork at Willendorf II. Quartär, 55, 9-15.

Nigst, P. R., Viola, B., Haesaerts, P., Blockley, S., Damblon, F., Franck, C., Götzinger, M., Hambach, U., Mallol, C., Moreau, L., Niven, L., Richter, D., Richards, M., Zöller, L., Hublin, J.-J., \& Trnka, G. (2008b). Neue Forschungen in Willendorf II: ein Vorbericht über die Grabung 2006. Mitteilungen der Anthropologischen Gesellschaft in Wien, 138, 79-88.

Nigst, P. R., Haesaerts, P., Damblon, F., Franck, C., Mallol, C., Viola, B., Götzinger, M., Niven, L., Trnka, G., \& Hublin, J.-J. (2014). Early modern human settlement of Europe north of the Alps occurred 43,500 years ago in a cold steppe-type environment. PNAS, 111(40), 14394-14399.

O'Farrell, M. (2005). Etude préliminaire des éléments d'armature lithique de l'Aurignacien ancien de Brassempouy. In F. Le Brun-Ricalens (Ed.), Productions lamellaires attribuées à l'Aurignacien, chaînes opératoires et perspectives techno-culturelles (pp. 395-412). Luxembourg: MNHA (ArchéoLogiques, 1).

Pääbo, S. (2015). The diverse origins of the human gene pool. Nature Reviews Genetics, 16, 313-314.

Palma di Cesnola, A. (1993). Il Paleolitico Superiore in Italia. Introduzione allo studio. Firenze: Garlatti \& Razzai.

Peresani, M., \& Centi Di Taranto, L. E. (2013). Blades, bladelets and flakes: a case of variability in tool design at the dawn of the Middle-Upper Palaeolithic transition in Italy. Comptes Rendus Palevol, 12(4), 211221.

Peyrony, D. (1933). Les industries "aurignaciennes" dans le bassin de la Vézère. Bulletin de la Société Préhistorique Française, 30, 543-559.

Smith, F. H., Janković, I., \& Karavanić, I. (2005). The assimilation model, modern human origins in Europe, and the extinction of Neandertals. Quaternary International, 137, 7-19.

Sonneville-Bordes, D. (1960). Le Paléolithique supérieur en Périgord. Bordeaux: Delmas.

Sonneville-Bordes, D. (1983). L'évolution des industries aurignaciennes. In Aurignacien et Gravettien en Europe (pp. 339-360). Liège: ERAUL.

Stuiver, M., \& Reimer, P. J. (1993). Extended ${ }^{14} \mathrm{C}$ data base and revised CALIB $3.0{ }^{14} \mathrm{C}$ age calibration program. Radiocarbon, 35(1), 215-230.

Szmidt, C. C., Brou, L., \& Jaccottey, L. (2010). Direct radiocarbon (AMS) dating of split-based points from the (Proto)Aurignacian of Trou de la Mère Clochette, northeastern France:implications for the 
characterization of the Aurignacian and the timing of technical innovations in Europe. Journal of Archaeological Science, 37, 3320-3337.

Tallavaara, M., Luoto, M., Korhonen, N., Järvinen, H., \& Seppä, H. (2015). Human population dynamics in Europe over the Last Glacial Maximum. Proceedings of the National Academy of Sciences USA, 112(27), 8232-8237.

Tartar, E., Teyssandier, N., Bon, F., \& Liolios, D. (2006). Equipement de chasse, équipement domestique: une distinction efficace? Réflexions sur la notion d'investissement technique dans les industries aurignaciennes. In L. Astruc, F. Bon, V. Léa, P.-Y. Milcent, \& S. Phillibert (Eds.), Normes techniques et pratiques sociales: de la simplicité des outillages pré- et protohistoriques (pp. 107-118). Antibes: ADPCA.

Teyssandier, N. (2007). En route vers l'Ouest. Les débuts de l'Aurignacien en Europe. Oxford: John and Erica Hedges Ltd. (BAR International Series 1638).

Teyssandier, N. (2008). Revolution or evolution: the emergence of the Upper Paleolithic in Europe. World Archaeology, 40(4), 493-519.

Teyssandier, N., \&Liolios, D. (2003). Defining the earliest Aurignacian in the Swabian Alb: the relevance of the Geißenklösterle (Baden-Württemberg, Germany) lithic and organic productions. In J. Zilhão \& F. d'Errico (Eds.), The chronology of the Aurignacian and of the transitional technocomplexes. Dating, stratigraphies, cultural implications (pp. 179-196). Lisboa: Instituto Português de Arqueologia (Trabalhos de Arqueologia, 33).

Teyssandier, N., \& Liolios, D. (2008). Le concept d'Aurignacien: entre rupture préhistorique et obstacle épistémologique. Bulletin de la Société Préhistorique Française, 105(4), 737-747.

Teyssandier, N., Bon, F., \& Bordes, J.-G. (2010). Within projectile range: some thoughts on the appearance of the Aurignacian in Europe. Journal of Anthropological Research, 66, 209-229.

Trinkaus, E. (2007). European early modern humans and the fate of the Neandertals. Proceedings of the National Academy of Sciences USA, 104, 7367-7372.

Trinkaus, E., Constantin, S., \& Zilhão, J. (Eds.). (2013). Life and death at the Peştera cu Oase: A setting for modern human emergence in Europe. Oxford: Oxford University Press.

Verna, C., Dujardin, V., \& Trinkaus, E. (2012). The Early Aurignacian human remains from La Quina-Aval (France). Journal of Human Evolution, 62, 605-617.

Villa, P., Boscato, P., Ranaldo, F. \& Ronchitelli, A. (2009). Stone tools for the hunt: points with impact scars from a Middle Paleolithic site in southern Italy. Journal of Archaeological Science, 36, 850-859.

Ward, G. K., \& Wilson, S. R. (1978). Procedures for comparing and combining radiocarbon age determinations: a critique. Archaeometry, 20(1), 19-31.

White, R. (2007a). Parures aurignaciennes en Aquitaine: quelques nouvelles observations. In H. Floss \& N. Rouquerol (Eds.), Les chemins de l'art aurignacien en Europe (pp. 249-258). Aurignac: Editions Muséeforum.

White, R. (2007b). Systems of personal ornamentation in the Early Upper Palaeolithic: methodological challenges and new observations. In P. Mellars, K. Boyle, O. Bar-Yosef, \& C. Stringer (Eds.), Rethinking the human revolution: new behavioural and biological perspectives on the origin and dispersal of modern humans (pp. 287-302). Cambridge: McDonald Institute for Archaeological Research.

White, M., \& Pettitt, P. (2012). Ancient digs and modern myths: the age and context of the Kent's Cavern 4 maxilla and the earliest Homo sapiens specimens in Europe. European Journal of Archaeology, 15, 1-30.

White, R., Mensan, R., Bourrillon, R., Cretin, C., Highamn, T. F. G., Clarke, A. E., Sisk, M. L., Tartar, E., Gardère, P., Goldberg, P., Pelegrin, J., Valladas, H., Tisnérat-Laborde, N., De Sanoit, J., Chambellan, D., \& Chiotti, L. (2012). Context and dating of Aurignacian vulvar representations from Abri Castanet, France. Proceedings of the National Academy of Sciences USA, 109(22), 8450-8455.

Wobst, H. M. (1974). Boundary conditions for Paleolithic social systems: a simulation approach. American Antiquity, 39(2), 147-178.

Zilhão, J. (2006). Aurignacian, Behavior, Modern. Issues of Definition in the Emergence of the European Upper Paleolithic. In O. Bar-Yosef \& J. Zilhão (Eds.), Towards a Definition of the Aurignacian (pp. 5369). Lisboa: American School of Prehistoric Research/Instituto Português de Arqueologia (Trabalhos de Arqueologia, 45).

Zilhão, J. (2009). Szeletian, not Aurignacian: a review of the chronology and cultural associations of the Vindija G1 Neandertals. In M. Camps \& P. R. Chauhan (Eds.), A sourcebook of Paleolithic transitions (pp. 407-426). New York: Springer.

Zilhão, J.(2013). Neandertal-modern human contact in western Eurasia: Issues of dating, taxonomy, and cultural associations. In T. Akazawa, Y. Nishiaki, \& K. Aoki (Eds.), Dynamics of learning in 
Neanderthals and modern humans. Volume 1: Cultural perspectives (pp. 21-57). Tokyo: Springer (Replacement of Neanderthals by Modern Humans Series).

Zilhão J., Banks, W. E., d'Errico, F., \& Gioia, P. (2015). Analysis of site formation and assemblage integrity does not support attribution of the Uluzzian to modern humans at Grotta del Cavallo. PLoS ONE, 10(7), e0131181. https://doi.org/10.1371/journal.pone.0131181

Zilhão, J., Anesin, D., Aubry, T., Badal, E., Cabanes, D., Kehl, M., Klasen, N., Lucena, A., Martín-Lerma, I., Martínez, S., Matias, H., Susini, D., Steier, P., Wild, E. M., Angelucci, D. E., Villaverde, V., \& Zapata, J. (2017). Precise dating of the Middle-to-Upper Paleolithic transition in Murcia (Spain) supports late Neandertal persistence in Iberia. Heliyon, 3, e00435. 